\title{
$z z-88-08-1809$
}

ENVIRONMENTAL ASSESSMENT OF THE HAWAII GEOTHERMAL

PROJECT WELL FLOW TEST PROGRAM

Environmental Analysis Section

Return to the Environmental Sciences Library Bldg $1505 \mathrm{Rm} 109$

NOVEMBER 1976 


\section{DISCLAIMER}

This report was prepared as an account of work sponsored by an agency of the United States Government. Neither the United States Government nor any agency Thereof, nor any of their employees, makes any warranty, express or implied, or assumes any legal liability or responsibility for the accuracy, completeness, or usefulness of any information, apparatus, product, or process disclosed, or represents that its use would not infringe privately owned rights. Reference herein to any specific commercial product, process, or service by trade name, trademark, manufacturer, or otherwise does not necessarily constitute or imply its endorsement, recommendation, or favoring by the United States Government or any agency thereof. The views and opinions of authors expressed herein do not necessarily state or reflect those of the United States Government or any agency thereof. 


\section{DISCLAIMER}

Portions of this document may be illegible in electronic image products. Images are produced from the best available original document. 
ENVIRONMENTAL ASSESSMENT OF TEE HAWAII GEOTHERMAL

PROJECT WELL FLOW TEST PROGRAM

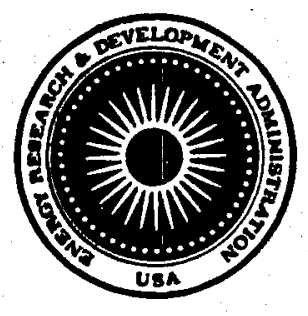

NOVEMBER 1976

UNITED STATES ERERGY RESEARCH AND DEVELOPLIENT ADMINISTRATION

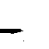

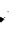

3445603329674 


\section{CONTENTS}

$\underline{\text { Page }}$

1. DESCRIPTION OF THE PROJECT . . . . . . . . . . . 1-1

1.1 BACKGROUND OF PROPOSED WELL TEST . . . . . . . . . . 1-2

1.2 THE PROPOSED FLOW TEST . . . . . . . . . . . . . 1-7

REFERENCE FOR SECTION 1............. 1-15

2. DESCRIPTION OF THE SITE AND ENVIRONS . . . . . . . . . 2-1

2.1 SITE LOCATION . . . . . . . . . . . . . . 2-1

2.2 DEMOGRAPHY ................... . . . 2-1

2.3 REGIONAL HISTORIC AND ARCHAEOLOGICAL SITES AND

NATURAL LANDMARKS ............... 2-4

2.4 GEOLOGY ................... 2-5

2.4.1 Structure, physiography, and stratigraphy . . 2-8

2.4.2 Tectonic history ............ 2-10

2.4 .3 Seismicity ............. . 2-12

2.4.4 Mineral resources ............. 2-14

2.4.5 known geothermal resources ........ 2-16

2.5 HYDROLOGY .................... 2-17

2.5.1 Groundwater ............. 2-17

2.5 .2 Surface water .............. 2-23

2.6 LAND USE................... 2-23

2.7 WATER USE ................ 2-26

2.8 CLIMATOLOGY . . . . . . . . . . . . . . 2-26

2.8.1 Temperature and humidity ......... . 2-27

2.8.2 Wind characteristics ... . . . . . . 2-28

2.8.3 Prectpitation . . . . . . . . . . 2-29

2.8.4 Storms and extreme weather ....... 2-30

2.8 .5 Alr quallty ............. . 2-31

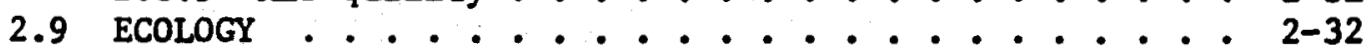

2.9 .1 Flora ................. 2-33

2.9 .2 Fauna . . . . . . . . . . . 2-34

2.9.3 Endangered species ........ 2-37

2.10 COMMUNITY CHARACTERISTICS AND GOVERNMENTAL

STRUCTURE . . . . . . . . . . . . 2-38

REFERENCES FOR SECTION 2 ............... 2-41

3. POTENTIAL ENVIROMMENTAL IMPACTS ............ 3-1

3.1 PHYSICAI ENVIRONMENT .............. . . 3-1

3.1.1 Land use ................... 3-1

3.1 .2 Water use ................ 3-2

3.1.3 Air quality ................ 3-3

3.1.4 Water quality ............ 3-5

3.2 IMPACTS ON THE BIOLOGICAL ENVIRONMENT . . . . . . 3-8

3.2.1 Impacts due to destruction of habitat . . . . 3-8

3.2.2 Impacts due to nolse .......... 3-9

3.2.3 Impacts due to gaseous effluents ....... 3-11

3.2.4 Impacts due to liquid effluents ....... . 3-12 
3.3. SOCIOECONOMIC EFFECTS .............. 3-12

3.4 IMPACT CONTROL PROGRAMS ............ 3-13

3.5 POTENTIAL ACCIDENTS .............. 3-14

3.6 POTENTIAI LONG-TERM ENVIRONMENTAL EFFECTS . . . . . 3-15

REFERENCES FOR SECTION $3 . . . . . . . . . . . . ~ 3-16$

4. CONFLICTS WITH FEDERAL, STATE, AND REGIONAL OR

LOCAL PLANS . . . . . . . . . . . . . . . 4-1 
Figure.

1.1 HGP-A casing program . . . . . . . . . . . 1-5

1.2 Schematic of HGP-A wellhead instrumentation . . . . . 1-6

1.3 Temperature vs pressure for HGP-A after 4-hr discharge, July 22, 1976 . . . . . . . . . . 1-8

1.4 Hawail Geothermal Project - flow test equipment and instrumentation ............... . 1-10

1.5 Well test and analysis program schedule . . . . . . 1-14

2.1 Location of HGP-A within Puna district of the Island of Hawaii . . . . . . . . . . . . . 2-2

2.2 Puna district showing HGP-A and surroundings . . . . 2-3

2.3 Relationship of the geothermal well site to the east rift zone of Kllauea . . . . . . . . . . 2-6

2.4 Location of sampled wells and spring, Puna, Hawaii . . 2-18 


\section{LIST OF TABLES}

Table

Page

1.1 Well test chronology of HGP-A, $1976 \ldots$. . . . . . 1-4

2.1 National historical sites on the Island of Hawail . . . 2-5

2.2 Historic eruptions of the east rift of Kilauea, 1750-1969 ................ 2-11

2.3 Distribution of earthquakes, 1834-1970 . . . . . 2-13

2.4 Chemical data, groundwater and rainwater, Puna, Hawall . . . . . . . . . . . . . . . 2-20

2.5 Microbiological quality of groundwater, Puna, Hawail . . . . . . . . . . . . . . . 2-21

2.6 Land use - Island of Hawail ............ 2-24

2.7 Existing land use in Puna district ......... 2-25

2.8 Sumbary of acreage for major agricultural activities in Puna .................. 2-25

2.9 Temperature ranges in and around Puna district . . . . 2-27

2.10 Air values for mercury, Is land of Hawail, May 22, 1975 . . . . . . . . . . . . . 2-31

2.11 Endangered wildlife of the Island of Hawail . . . . 2-39

2.12 Summary of employment statistics for major agricultural activities in Puna .......... 2-40

3.1 Comparison of past and current fixed gas aerometric data at the Sulfur Banks and HGP drill site (Puna) . . . . . . . . . . . 3-4

3.2 Aerometric data for June 24-26, 1976, at HGP-Puna and other sites, Island of Hawali . . . . . . 3-4

3.3 Common sound levels ................... 30

3.4 Permissible noise exposures ......... 3-14 


\section{DESCRIPTION OF THE PROJECT}

The Hawali Geothermal Project, a coordinated research effort of the University of Hawail, funded by the County and State of Hawail, and ERDA, was initiated in 1973 in an effort to identify, generate, and use geothermal energy on the Big Island of Hawaif. A number of stages are involved in developing geothermal power resources: exploration, test drilling, production testing, field development, power plant and powerline construction, and full-scale production.

Phase I of the Project, which began in the sumer of 1973, involved conducting exploratory surveys, developing analytical models for interpretation of geophysical results, conducting studies on energy recovery from hot brine, and examining the legal and economic implications of developing geothermal resources in the state. Phase II of the Project, Initiated in the sumer of 1975, centers on drilling an exploratory research well on the Island of Hawail, but also continues operational support for the geophysical, engineering, and socioeconomic activities delineated above. The project to date is between the test drilling and production testing phase.

The drilling phase was successfully completed at the drill site on the edge of the 1955 lava flow on the Pahoa-Pohoik1 Road 4 miles from Pahoa (Sect. 2.1). The we11, referred to as HGP-A, has been drilled to a depth of $1900 \mathrm{~m}(6450 \mathrm{ft})$. Inttlal data indicate downhole temperatures in excess of $300^{\circ} \mathrm{C}\left(570^{\circ} \mathrm{F}\right)$. Downhole water samples indicate an anomalous 
situation of potentially fresh water as the geothermal fluid (Sect. 2.4). Long-term flow testing will be necessary to substantiate this finding.

Investigations thus far concluded have provided initial baseline data describing the existing environmental setting of the drilling site and vicinity before drilling was begun. Data gathering has continued throughout the drilling phase and will continue throughout production testing operations so that changes to the environs of the immediate drilling area can be detected. This type of comparative data is essential to the development of mitigating measures that will provide for environmentally acceptable field operations if feasibility is demonstrated. These initial baseline investigations serve as an essential part of this environmental impact assessment.

The purpose of this assessment is to describe the activities and potential impacts associaced with extensive well flow testing to be completed during Phase II.

\subsection{BACKGROUND OF PROPOSED WELL TEST}

After drilling of HGP-A, installation of a slotted liner, and indication of extremely high bottom-hole temperatures, the next major phase In the Hawali Geothermal Project is a flow test and analysis program designed to determine the properties of the well, fluid, and reservoir. The program described below was formulated as the first step to obtaining this information. 
The objectives of the well test and analysis program are to (1) determine well and reservoir characteristics; (2) obtain data useful for drilling future wells; (3) determine problem areas relative to well production; (4) determine possible environmental problems; and (5) remedy possible skin damage in the well.

A brief record of important events which have happened to the well since the completion of drilling on April 27, 1976, is given in Table 1.1. Water injection tests were completed on June 6 with the mud pumps still present at the drill site. HGP-A has been flashed four times for varying periods - once on July 2, a second time on July 19, a third time on July 21 to check instrumentation, and then for a longer period of $4 \mathrm{hr}$ on July 22 to obtain preliminary values for wellhead pressure and temperature and total mass flow rate. Beginning on April 29, temperature and pressure profiles in the well bore were obtained at various times, and beginning on August 19, water at different depths in the well bore was sampled to obtain chemical analyses.

The 4-hr well flashing on July 22 was accomplished by using the casing program shown in Fig. 1.1 and the wellhead instrumentation shown in Fig. 1.2. The sonic flow, lip pressure method ${ }^{2}$ was used to obtain total mass flow with lip pressure being measured at the end of a vertical 6-in. discharge tube. In addition, an 8-in. discharge tube mounted horizontally was also flowed for a brief time. Wellhead pressure and temperature were obtained from a bleedline controlled by a 2-in. valve. 
Table 1.1. Well test chronology of HGP-A, 1976

\begin{tabular}{|c|c|}
\hline Date & Event \\
\hline Apr. 27 & Drilling completed to $6450 \mathrm{ft}$ \\
\hline Apr. 29-May 24 & Well bore temperature profiles measured \\
\hline May 27-June 1 & Slotted liner installed \\
\hline June 6 & Water injection tests \\
\hline June $7-20$ & $\begin{array}{l}\text { Well bore temperature and pressure } \\
\text { profiles measured }\end{array}$ \\
\hline $\begin{array}{l}\text { June } 22-24 \\
\text { June } 26 \text { and } 30\end{array}$ & $\begin{array}{l}\text { Unsuccessful attempt to flash HGP.A } \\
\text { Temperature and pressure profiles measured }\end{array}$ \\
\hline July 2 & HGP-A flashed for $4 \mathrm{~min}$ \\
\hline July 3-19 & $\begin{array}{l}\text { Well flowed twice daily to maintain casing } \\
\text { temperature }\end{array}$ \\
\hline July 19 & Well flashed for $50 \mathrm{~min}$ \\
\hline July 20-21 & $\begin{array}{l}\text { Well flowed twice daily to maintain casing } \\
\text { temperature }\end{array}$ \\
\hline July 21 & Well flashed for $30 \mathrm{sec}$ \\
\hline July 22 & Well flashed for $4 \mathrm{hr}$ \\
\hline July 22-Aug. 18 & Temperature and pressure profiles measured \\
\hline Aug. 19 & $\begin{array}{l}\text { Water samples obtained at different depths } \\
\text { in well bore }\end{array}$ \\
\hline Aug. 26 & Temperature and pressure profiles measured \\
\hline
\end{tabular}


ES 3033

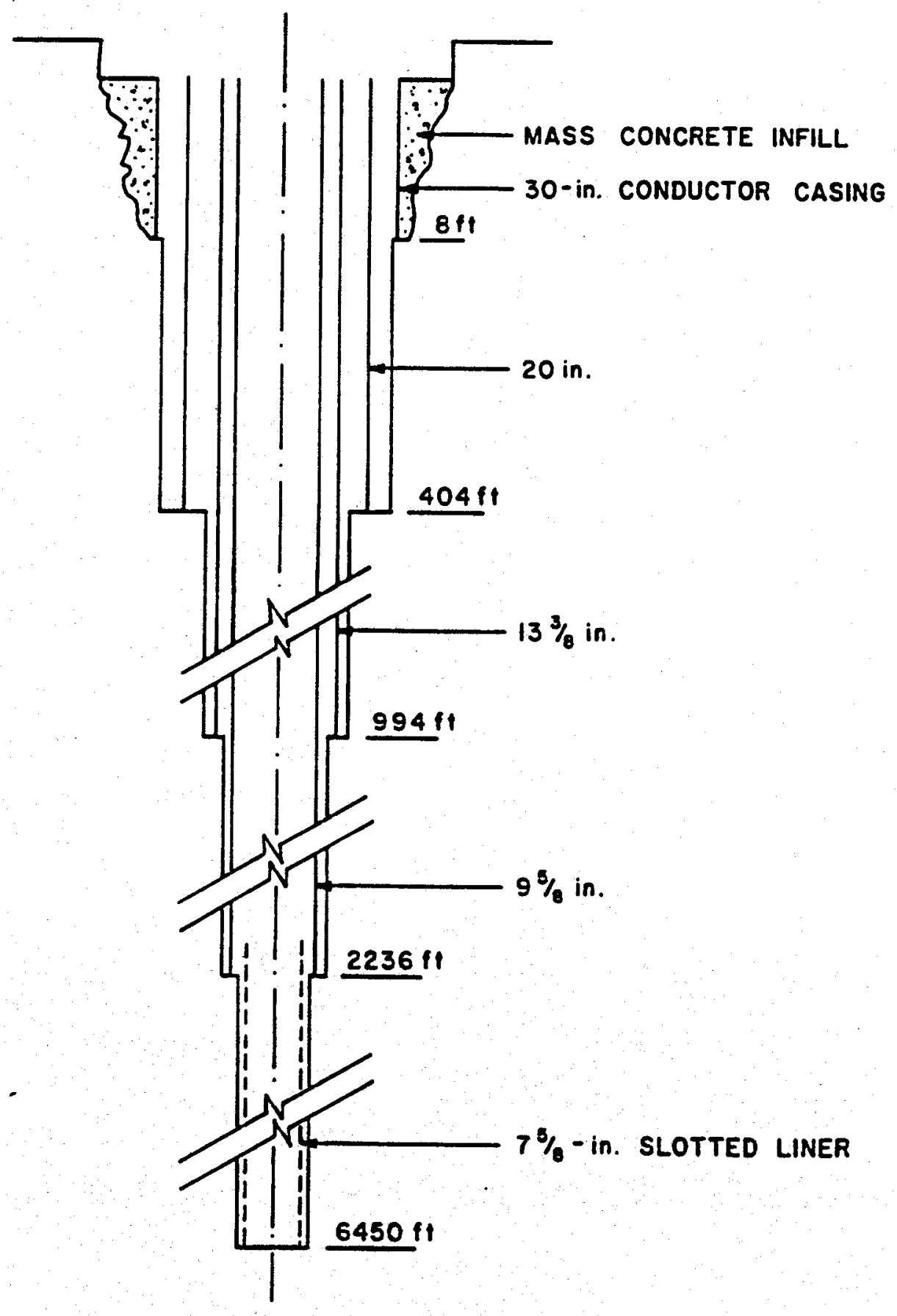

Fig. 1.1. HGP-A casing program. 


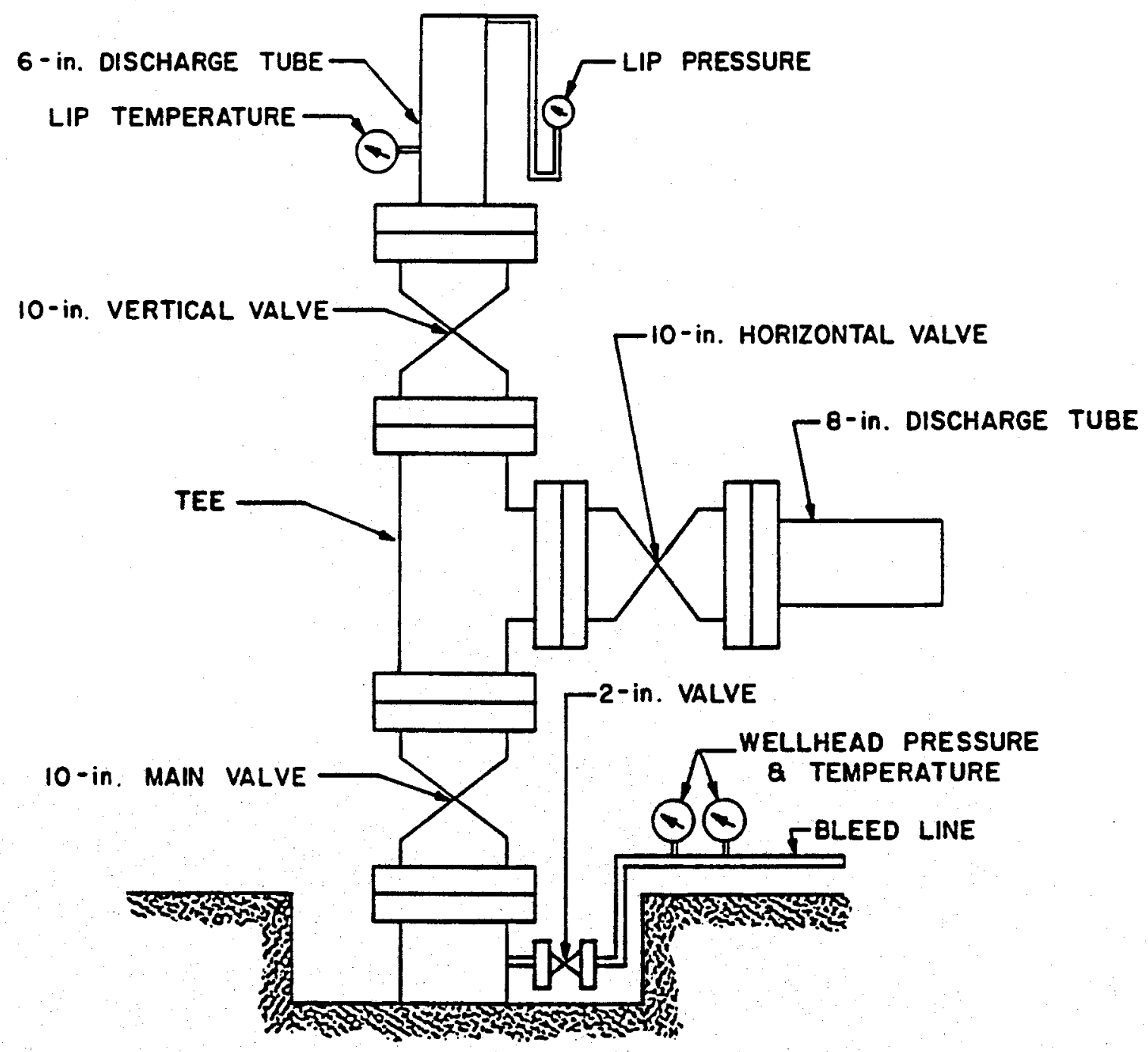

Fig. 1.2. Schematic of HGP-A wellhead Instrumentation. 
The lip pressure at the end of the 4-hr flashing was 23 psig, which corresponds to a mass flow of about $220,000 \mathrm{lb} / \mathrm{hr}$ if assuming a specific enthalpy of $405 \mathrm{cal} / \mathrm{g}(600 \mathrm{Btu} / \mathrm{lb})$. Using this figure for specific enthalpy and assuming a conversion efficiency of $15 \%$ leads to a usable electric power equivalent of a little over $5 \mathrm{MW}$.

Figure 1.3 shows a plot of temperature vs pressure for HGP-A a few hours after the 4-hr flashing on July 22. The number adjacent to each data point represents the depth of that data point with respect to the surface at the well site. Also on the figure is the boiling point curve for pure water. As can be seen, the flash point in the well bore appeared to have reached a depth slightly greater than $1400 \mathrm{~m}$ (4600 ft) below the surface at the well site.

Measurements of temperature vs depth and of pressure vs depth for HGP-A for up to $2-1 / 2$ months after the flashing indicate that the major production region is probably between 1070 (3500) and $1370 \mathrm{~m}$ (4500 ft) deep and that a lesser-producing zone of probably lower temperature may exist around $1830 \mathrm{~m}(6000 \mathrm{ft})$.

\subsection{THE PROPOSED FLOW TEST}

Tests and analyses planned for the proposed flow test covered by the assessment include (1) temperature and pressure profiles; (2) sustained long-term discharge; (3) varlable flow-rate discharge; (4) pressure drawdown and buildup; (5) steam quality; (6) casing integrity; (7) cold 


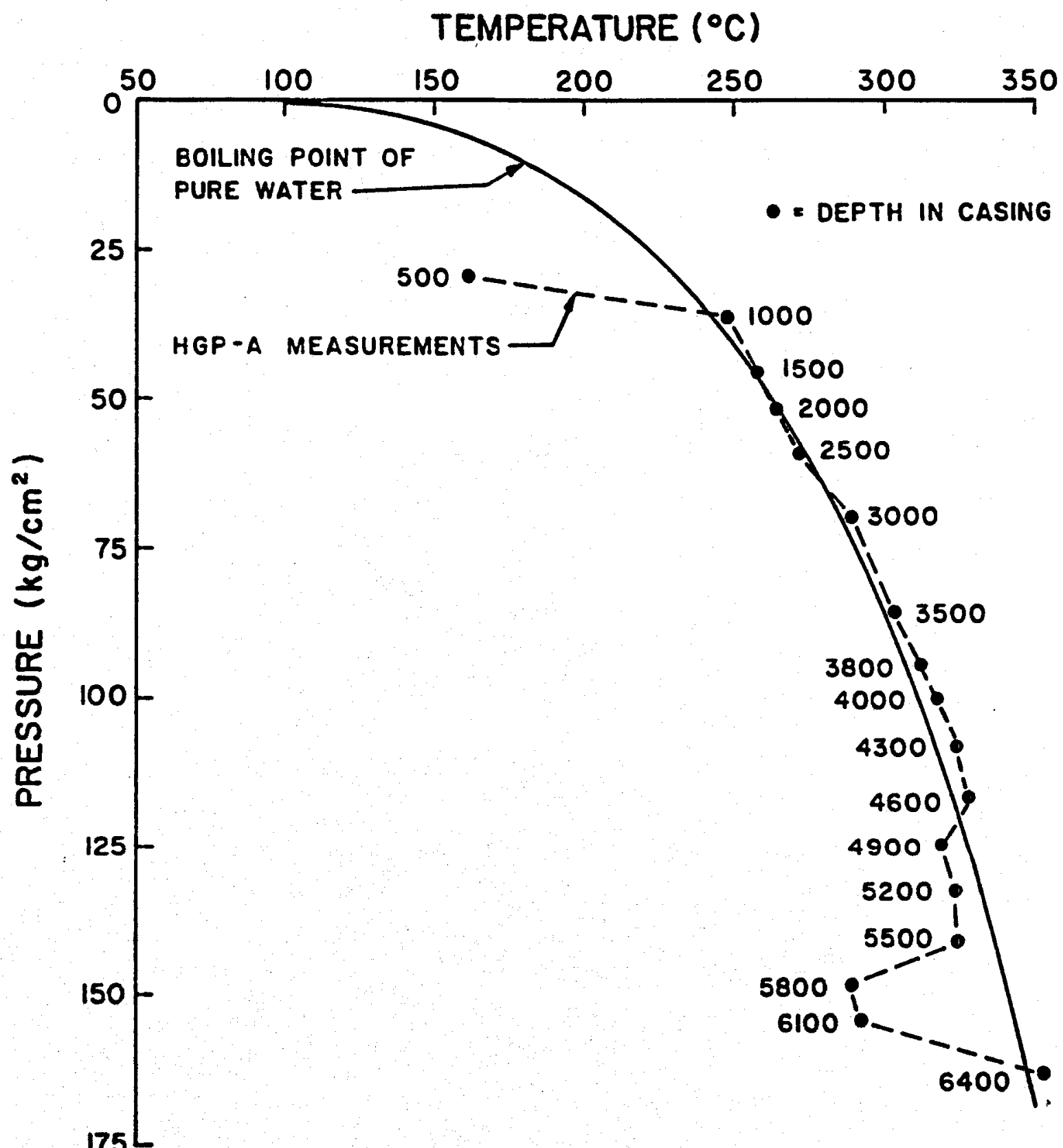

F1g. 1.3. Temperature vs pressure for HGP-A after 4-hr discharge, July 22, 1976. 
fluid influx; (8) downhole flowmeter; (9) interference tests using observation water wells; (10) scaling and corrosion effects of effluent; and (11) chemical analyses of downhole water samples.

Figure 1.4 is a sketch of the planned equipment and instrumentation for the discharge test. As shown, the method involves basically the James techniquel for measuring total mass flow with twin cyclone separators for silencing and separation of steam and water. A $90^{\circ}$ notch weir will be used to measure the liquid flow rate, permitting calculation of steam quality and specific enthalpy. In addition, a calorimeter will be used to provide an independent measurement of the specific enthalpy. A 2-in. twin cyclone sampler will be used to obtain gas and vapor samples for chemical analyses, and a recovery tube will be mounted on the wellhead to permit temperature and pressure profiles to be obtained during the flow test.

During the period when the well test equipment is being built and installed, preliminary tests w11l be undertaken prior to actual flashing flow. First there will be a casing integrity test to determine whether any collapse of the casing has occurred. A "go-devil," having an outside diameter slightly smaller than the actual casing diameter of 8.755 in., will be lowered slowly on a wire line to probe for any significant blockage of the well bore.

A second test will involve slow, nonflashing flow through the bleed line until roughly three times the casing volume has been emptied. Fluid 
ES 3038

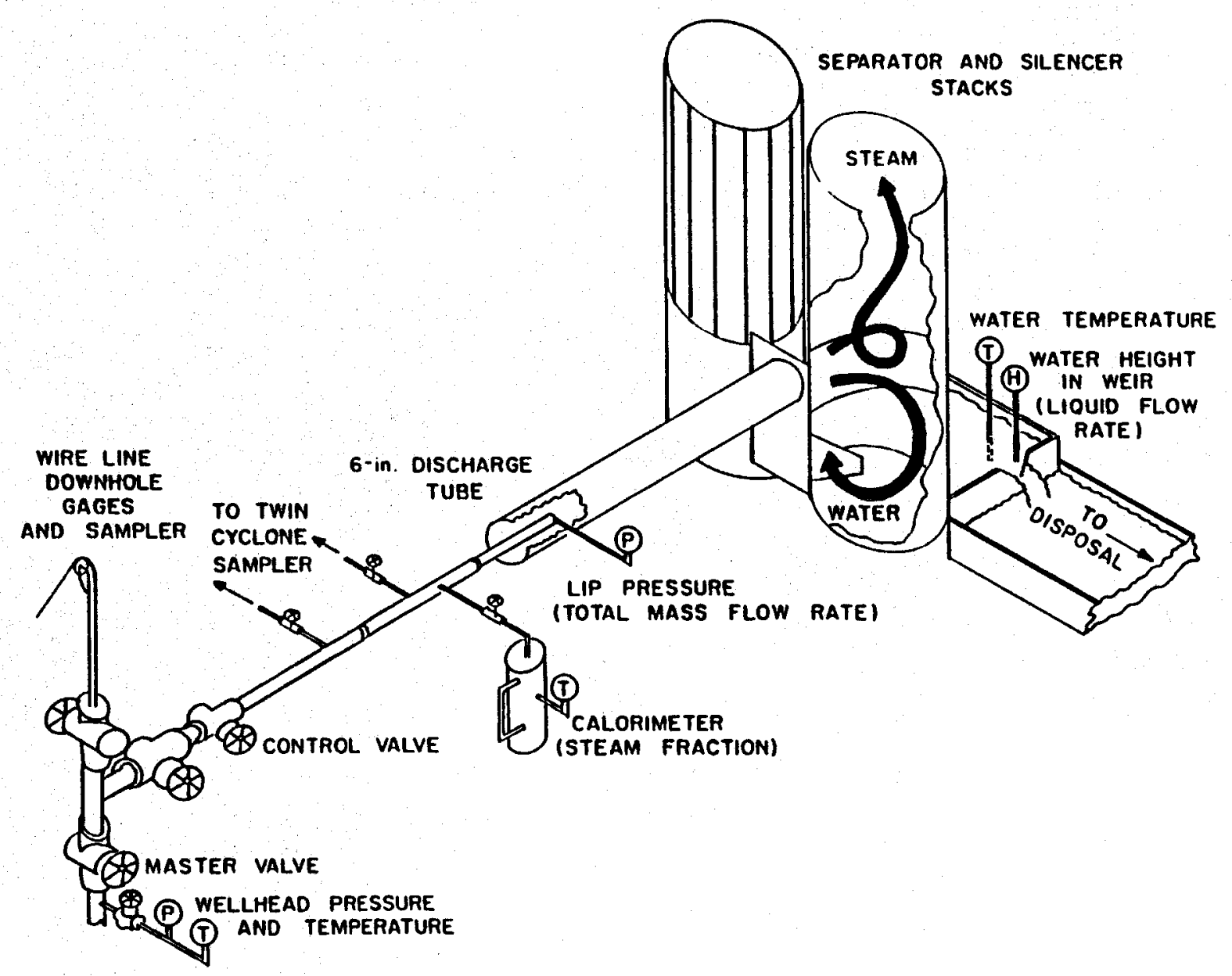

Fig. 1.4. Hawaii Geothermal Project - flow test equipment and Instrumentation. 
temperatures will be monitored at the wellhead and at various depths during this period, and water samples will be taken before and after the test. Analysis of the temperature and chemical data should give some indication of whether there is cold fluid entering the well bore over the casing depth or at the junction of casing and liner.

Following this phase, the flow rate through the $2-1 n$. bleed line will be increased gradually until flashing flow is achieved. This gradual increase will permit the wellhead casing to reach operating (flashing) temperature without being subjected to stresses associated with sudden Increases in temperature.

Once the system temperatures are at operating levels, sustained flow testing will be performed in several tests over a six-month period. First, tests to determine the production capacity of HGP-A will be undertaken. During this phase the well will be allowed to flow at various fractions (e.8., 10, 25, 50, 75, or 100\%) of wide-open flow for a total period of about one month. Measurements taken during this series of tests will allow determination of production flow rate and steam fraction as functions of wellhead conditions. This information, along with chemical analyses of samples of steam, liquid, and noncondensable gases, will ald in the future selection of an energy conversion system - that is, whether it will be a permanent unit or a small portable unit to be used in confunction with further testing of HGP-A. 
A longer-term, sustained discharge test will follow the production capacity tests for the purpose of estimating reservoir characteristics. For this phase the well will be flowed at a constant rate for periods of two weeks or longer, and transient pressure measurements will be taken at the bottom of the well. The pressure drawdown and buildup (after the well is shut in) data will allow a rough estimate of the permeability and extent of the reservoir to be made. Also to be measured are the characteristics of the effluent (temperature, specific enthalpy, chemical composition, etc.) to detect any changes in the producing zones or to alleviate possible skin damage.

In an attempt to pinpoint the producing zones, downhole flowmeter tests are being contemplated. If these tests prove feasible, downhole flowmeters will be placed so as to straddle a suspected producing zone, providing information leading to a determination of the fluid produced in that stratum.

In conjunction with these sustained long-term discharges, the water levels of several water wells in the immediate vicinity will be monitored. Any measurable changes will be Incorporated in the evaluation of the reservoir.

Concurrent with the well production testing and reservoir evaluation phases, tests will be conducted to evaluate the scaling and corrosion effects of the effluent. Specimens of various materials will be located (1) on the separator wall, (2) in the iiquid behind the weir, 
and (3) in the air surrounding the discharge and will be examined periodically.

Throughout the course of the well testing program, downhole water samples and temperature and pressure profiles will be taken during those intervals when the well is shut in or is being bled through the 2-in. bleed line.

Figure 1.5 is a time schedule for the tests described. The proposed well test will run for a period of six months - November 1, 1976 to April 30, 1977. About 1 million gpd will flow during full flashing. Smaller volumes will be released during the startup phase (15 to 20 days) and during variable flow tests. The fluids will flow into a sump dug into the basaltic substrate. The sump will be about $6 \times 6 \mathrm{~m}$ (20 $\times 20 \mathrm{ft})$ and will be dug to a depth that will allow percolation through the basalt.

The maximum number of workers at the site is expected to be less than 25. 


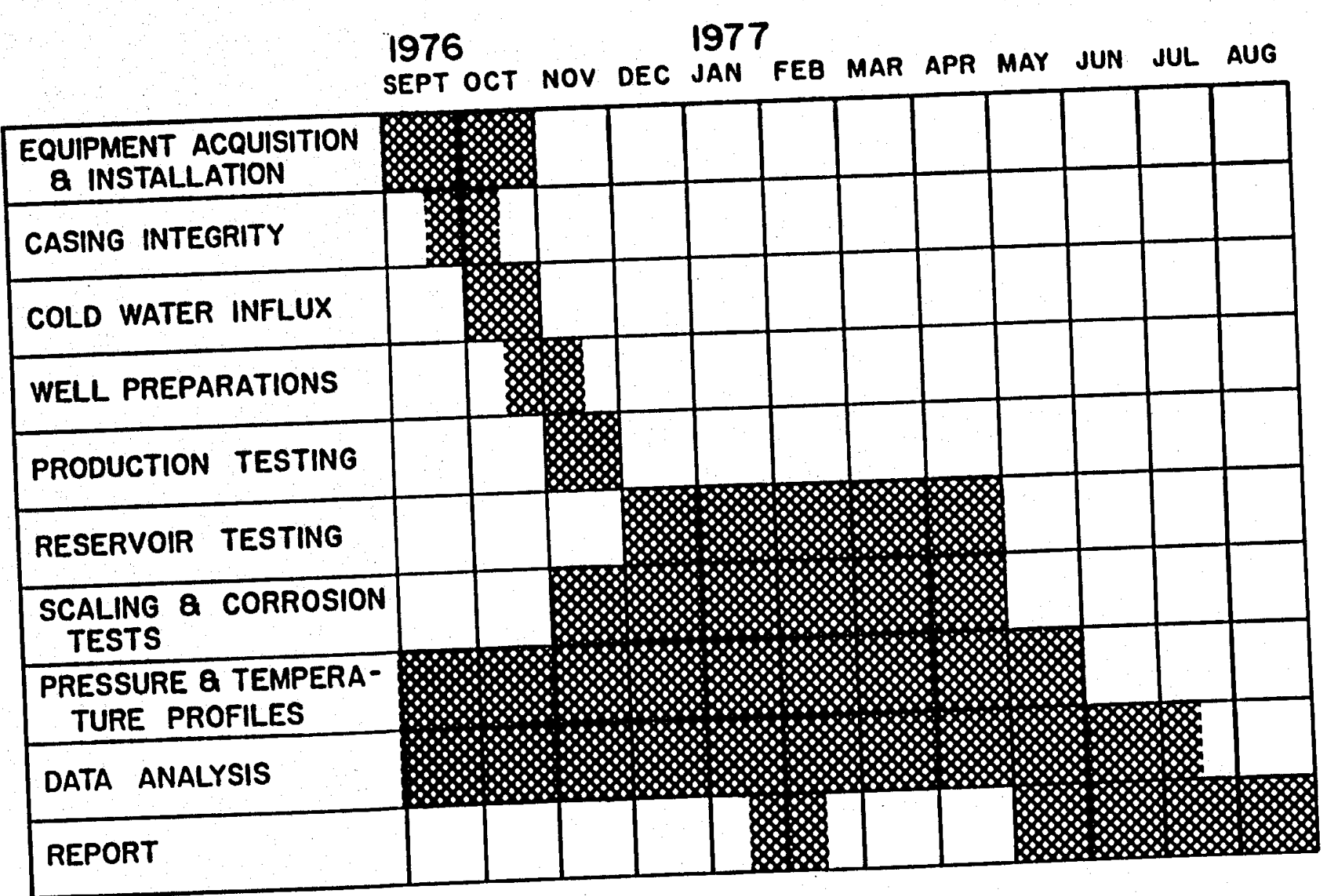

Fig. 1.5. We1l test and analysis program schedule. 
REFERENCE FOR SECTION 1

1. Russell James, "Measurement of Steam-Water Mixtures Discharging at the Speed of Sound to the Atmosphere," N. 2. Eng., Pp. 437-41 (October 1966). 


\section{DESCRIPTION OF THE SITE AND ENVIRONS}

\subsection{SITE LOCATION}

The HGP-A well location is in the Puna district on the eastern side of the Big Island, Hawaii (Fig. 2.1). Puna represents about $15 \%$ of the land area of the Island. The site is about $6.4 \mathrm{~km}$ ( 4 miles) ESE of the town of Pahoa adjacent to the Pahoa-Pohoikf Road $\left(19^{\circ} 28^{\prime} 30^{\prime \prime} \mathrm{N}\right.$ by $\left.154^{\circ} 53^{\prime} 30^{\prime \prime} \mathrm{W}\right)$ (Fig. 2.2).

The $\mathrm{Pu}$ 'u Honualoa volcano is about $1.2 \mathrm{~km}(0.75 \mathrm{mile})$ NE of the site and is easily visible from the site. The Pu'ulena, Pawai, and Kahuwai craters are located at about the same distance south of the site. Lava Tree State Park is $1.6 \mathrm{~km}$ ( $1 \mathrm{mlle}$ ) north of the site, and a University of Hawail Experimental Station is located $1.6 \mathrm{~km}$ ( 1 mile) south of the site.

The site itself includes the well and surrounding area, a parking area, a large storage shed, and a 681,000-11ter (180,000-ga1) lined water storage reservoir. The total area of activity is less than 15 acres.

\subsection{DEMOGRAPHY}

The Puna district is sparsely populated. The nearest population center Is the town of Pahoa, about $6.4 \mathrm{~km}$ (4 miles) NW of the site. Pahoa is an agricultural communtty and has only about 900 residents. The largest city on the Island is Hilo (population 26,353) some $24 \mathrm{~km}$ (15 miles) north 


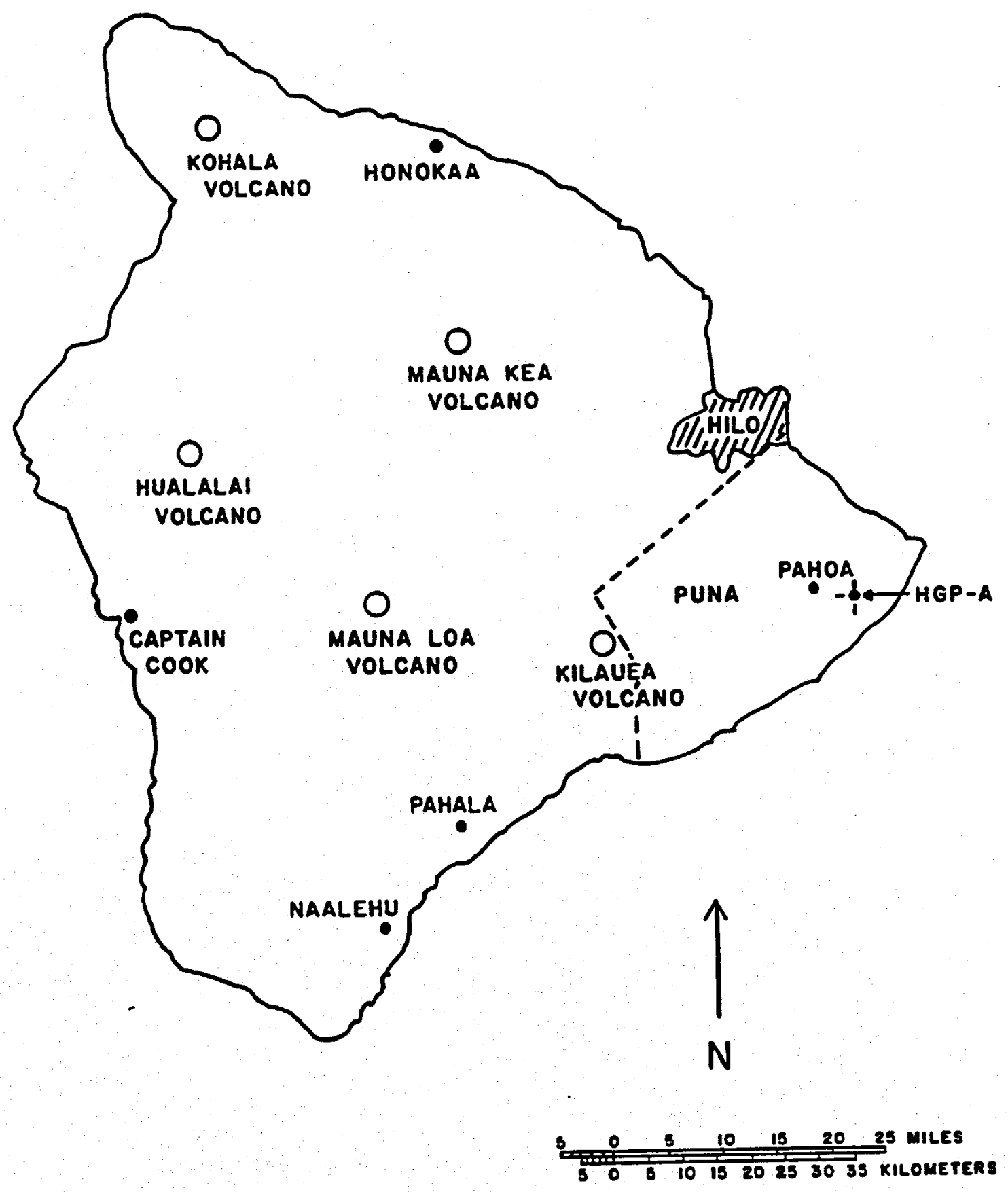

F1g. 2.1. Location of HGP-A within Puna district of the Island of Hawail. 


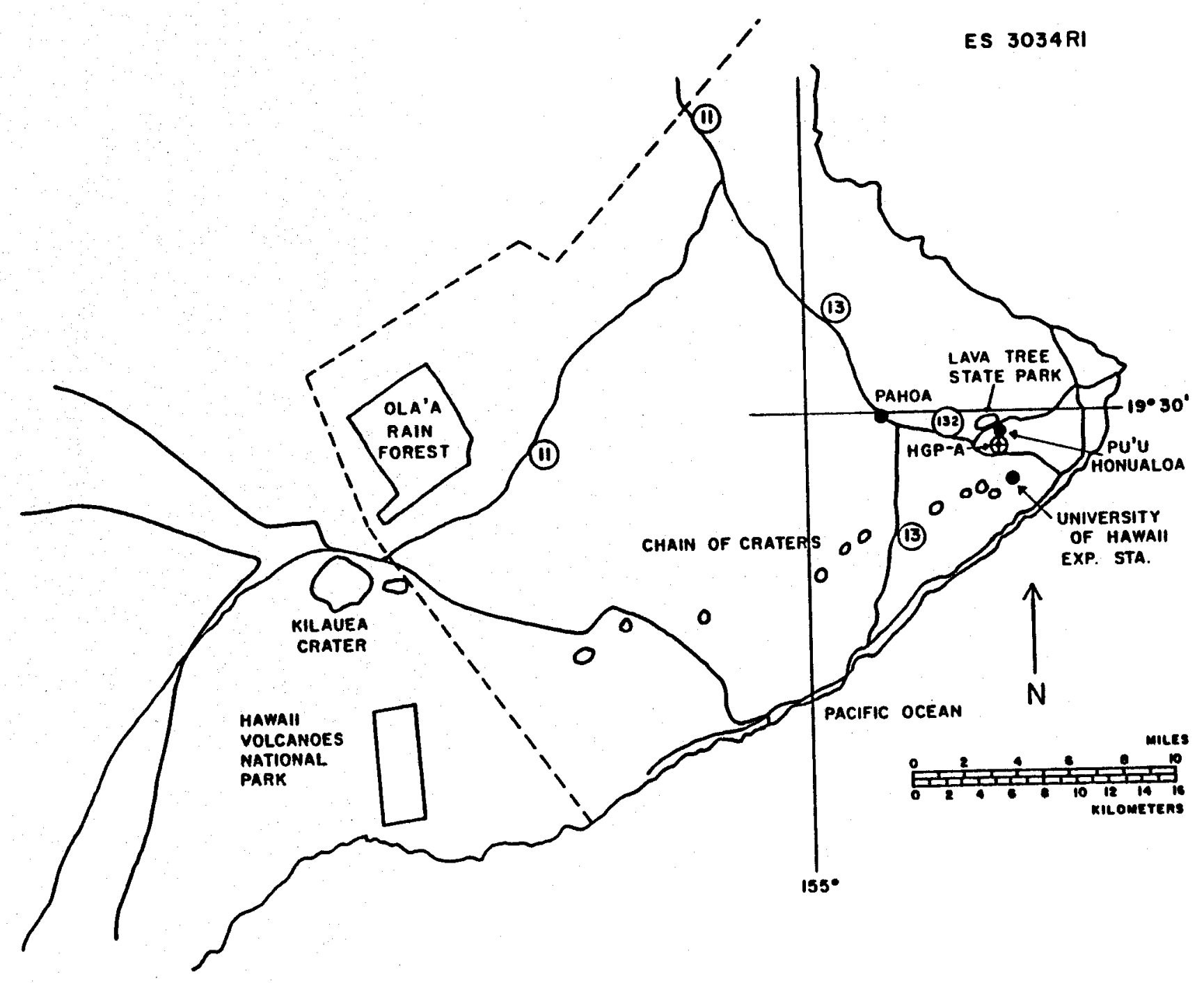

Fig. 2.2. Puna district showing HGP-A and surroundings. 
of the site. Towns on the Big Island having a population greater than 1000 are Pahala, Naalehu, Captain Cook, Honokoa, and Papaikau; all have populations less then 2500 (Fig. 2.1).1 The resident population of the Island is 63,468 with a mean density of 16 persons/sq mile (Ref. 2).

There is only one occupied dwelling within a $1.6-\mathrm{km}$ (1-mile) radius of the site. There is a residential development $3.2 \mathrm{~km}$ ( $2 \mathrm{miles}) \mathrm{NW}$ of the site, but there are no occupants at this time.

\subsection{REGIONAL HISTORIC AND ARCHAEOLOGICAL SITES AND NATURAL LANDMARKS}

Two locations on the Island of Hawail are listed in "The National Registry of Natural Landmarks" - Mauna Kea and the Makalawena Marsh. 3 Both are located north and west, far removed from the site.

Historically, Puna has played a relatively insignificant role in the centuries of Polynesian civilization. Puna produced no important family or chief and was dominated by the bordering districts of Hilo and $\mathrm{Ka}{ }^{\prime} \mathrm{u}$.

Table 2.1 lists the national historic sites on the Island of Hawaif; however, the area imediately surrounding the exploratory drilling site consists of recent as well as prehistoric lava flows. As a result of the 1955 eruption of the Kilauea volcano, any archaeologically or historically significant material within the area, or for that matter within the region, if present prior to this environmental change, would have been covered by lava flow. 
Table 2.1. National historical sites on the Island of Hawaii

\begin{tabular}{|c|c|c|}
\hline Name & Location & Comment \\
\hline Mookini Heiau & $\begin{array}{l}\text { Northern tip of island, } \\
1 \text { mile west of Upolu Airport; } \\
>100 \text { miles from site }\end{array}$ & Sacrificial temple \\
\hline Mauna Kea ADZ Quarry & $\begin{array}{l}25 \text { miles NW of Hilo; }>50 \text { miles from } \\
\text { site }\end{array}$ & Prehistoric quarry \\
\hline $\begin{array}{l}\text { City of Refuge National } \\
\text { Historical Park }\end{array}$ & $\begin{array}{l}20 \text { miles south of Kailua Kona; } \\
>70 \text { miles from site }\end{array}$ & $\begin{array}{l}\text { Site of sanctuary for all } \\
\text { who sought asylum }\end{array}$ \\
\hline Honokohau Settlement & $\begin{array}{l}\text { Honokohau Bay, just north of } \\
\text { Kailua Kona; >100 miles from site }\end{array}$ & Prehistoric settlement \\
\hline $\begin{array}{l}\text { Kamokahonu, Residence of } \\
\text { King Kamehameha I }\end{array}$ & $\begin{array}{l}\text { NW edge of Kailua Bay, north } \\
\text { and west of Kailua Wharf; }>70 \\
\text { miles from site }\end{array}$ & Residence of King Kamehameha I \\
\hline Puukohola Heiau & $\begin{array}{l}\text { North end of island, } 1 \text { mile } \\
\text { SE Kawaihae; }>90 \text { miles from site }\end{array}$ & $\begin{array}{l}\text { Temple associated with rise } \\
\text { of power of King Kamehameha I }\end{array}$ \\
\hline South Point Complex & $\begin{array}{l}\text { Southern tip of island: } \\
>70 \text { miles from site }\end{array}$ & Prehistoric habitat \\
\hline Heiau in Kupuipahu & $\begin{array}{l}\text { Hawaii vicinlty: }>100 \text { miles } \\
\text { from site }\end{array}$ & Elaborate temple \\
\hline Hulihee Palace & $\begin{array}{l}\text { Kailua Kona; >90 miles from } \\
\text { site }\end{array}$ & Residence of past governor \\
\hline
\end{tabular}

Source: U.S. Dept. of the Interior, The National Register of Historic Places, 1972; and Supplement to the National Register of Historic Places, 1974.

Examination of this lava-covered region, as well as the older ground cover within the study area, failed to uncover any evidence of archaeological sites, artifacts, or other data that would indicate prehistoric occupation or activity in this tract of land.

\subsection{GEOLOGY}

The southeastern part of the Island of Hawal1 is dominated by an asymetrical shleld volcano (KIlauea) and Its associated rift zones (FIg. 2.3). The east rift zone is of particular interest because it 


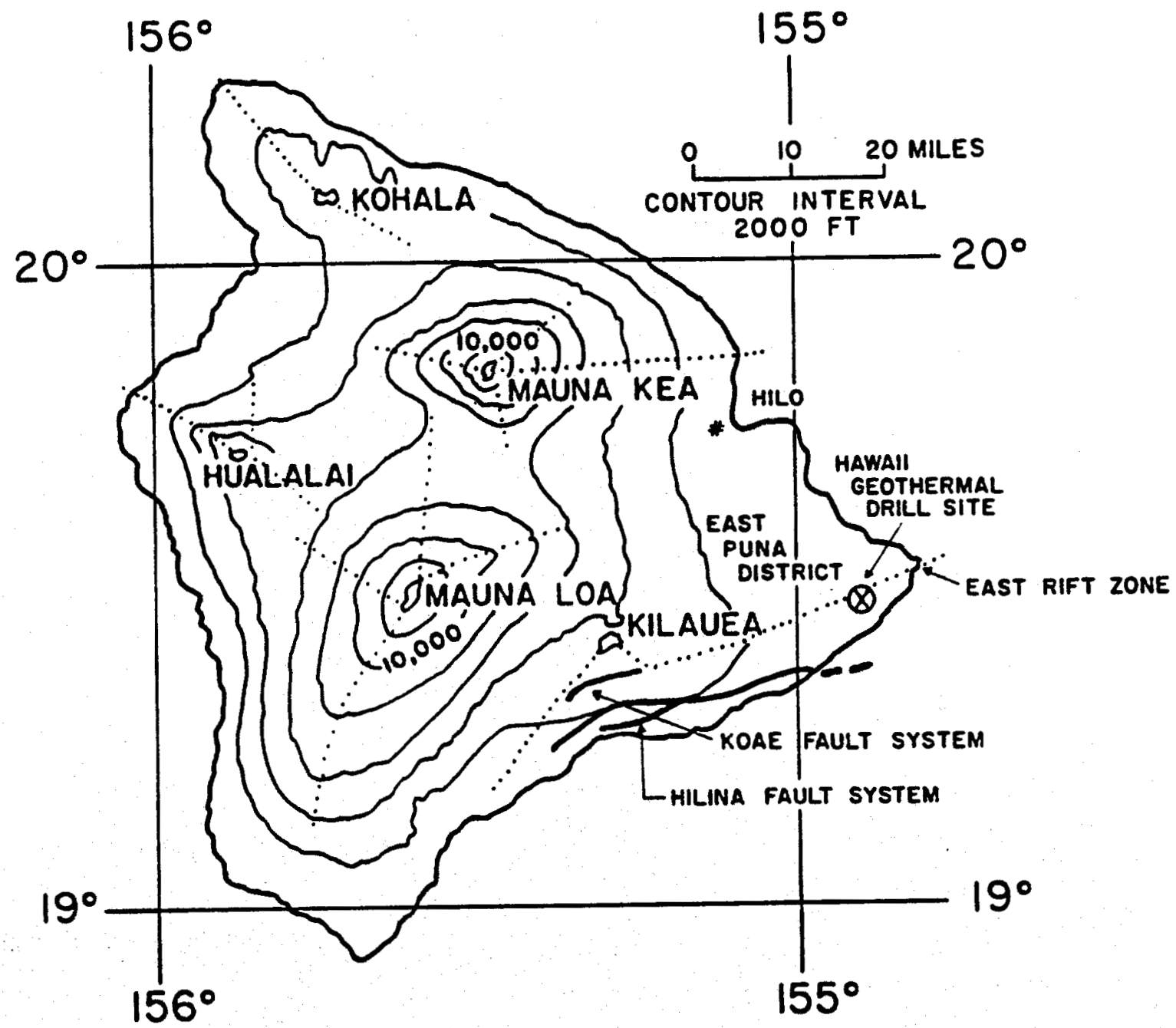

Fig. 2.3. Relationship of the geothermal well site to the east rift zone of Kilauea. 
passes through the Puna district and the geothermal well is located within $1 t$. The southwest rift zone extends into the $\mathrm{Ka}$ 'u district, 50 or more kilometers $(30 \mathrm{miles})$ west of the well site. ${ }^{4}$ Two fault systems, the Hillna and Koae systems (Fig. 2.3), are also related to Kilauea.

It is believed that magma in this region rises as a plume from depths of 50 to $75 \mathrm{~km}$ ( 30 to 45 miles) within the earth's mantle. Two centers of eruption of this magma at the surface have been active in the past two centuries - Kilauea and its larger neighbor to the west, Mauna Loa. Mauna Loa was more active throughout the nineteenth and the first half of the twentieth century, but K1lauea has been more active since the 1950s. A third volcano, Hualalai, has been dormant since 1801. Whereas Mauna Loa achieved its present size by the end of the Ice Age, Kilauea is probably still in its growth stage. It is probable that kilauea and Mauna Loa are fed by separate magma chambers because, except in 1868 , there are no historic periods when the two volcanoes erupted within brief time intervals of one another. 4

Major eruptions of KIlauea occur as flank eruptions. As KIlauea begins to swell, lava wells up in the caldera. Then flank eruptions burst through the surface along one or both of the principal rift zones. As the flank eruptions take place, the caldera at Kilauea subsides.

Earthquakes always accompany the eruptions. Earthquake precursors increase in frequency and Intensity as $\mathrm{K}$ llauea swells over a several-month 
period preceding a flank eruption. Seismicity reaches a peak as eruption commences and continues sporadically as long as $\mathrm{Kilauea}$ continues to subside and the flank eruptions persist.

Earthquake activity does not always culminate in volcanic eruption. An earthquake swarm took place in the Puna district in 1924 without the occurence of volcanism. This led the residents of the comunity into a false sense of security when, in 1955, earthquake swarms were followed by massive eruptions that lasted intermittently for 88 days. 4

\subsubsection{Structure, physiography, and stratigraphy}

The detailed geologic discussions that follow are largely directed to the east rift zone, where the well site is located. The east rift zone trends $6.4 \mathrm{~km}$ ( 4 miles) SE from the caldera of kilauea. It then turns $N 65^{\circ} \mathrm{E}$ and extends to Cape Kumukahi, the easternmost point of the Puna district. From there, it passes out to sea for a distance of perhaps $115 \mathrm{~km}$ (70 miles). 4

The rift zones of the Hawailan volcanoes differ from the major rifts that form boundarles between crustal plates as they are being pulled apart. In the latter case, the rift extends beneath the ocean floor and magma rises directly from below. In the case of the Hawaiian volcanoes, however, the rift zone is not belleved to extend below the ocean floor; the lava migrates laterally from the shield volcano (e.g., Kilauea), producing flank eruptions up to $160 \mathrm{~km}$ (100 miles) away • 
The east rift zone has several distinctive physiographic features. It is linked to the caldera of Kllauea by a series of pit craters, which are rather unevenly distributed. Within $1.2 \mathrm{~km}(0.75$ mile) south of the well site are located three pit craters - Pu'ulena, Pawai, and Kahuwai. About sixty spatter and cinder cones and two parasitic shield volcanoes are also found along the east rift zone. A 45-m (150-ft) cinder cone, Pu'u Honualoa, lies about $1 \mathrm{~km}(0.6 \mathrm{mile}) \mathrm{NE}$ of the well site (Fig. 2.2). Finally, there are a number of slightly eroded fault scarps. Older lava flows are truncated by these scarps, which are, in turn, covered by more recent lava flows. 4,5

The stratigraphic section exposed in the $\mathrm{Ka} \cdot \mathrm{u}$ and Puna districts is divided into two volcanic series. The lower (older) series is called the Hilina and is separated from the upper series (Puna) by the Pahala ash, a sandy to silty vitric yellow ash. Both series consist of oceanic basalt lava flows, together with cinder cones and ash deposits. The Hilina volcanic series is a succession of thin lava flows with a cumulative thickness of at least $304 \mathrm{~m}$ (1000 ft). The overlying Puna series ranges from one or two thin flows to perhaps more than $128 \mathrm{~m}$ ( $420 \mathrm{ft})$ thick. The Puna series has been erupted entirely from Kilauea caldera and the rift zones radiating from it. 5

Although a few intrusive rocks are exposed in $\mathrm{Kilauea}$ and Its rift zones, they are not well exposed because of 1Imited erosion. They are mainly vertical dikes that are a few inches to a few feet wide. They are well exposed in the walls of caldera, and some strike parallel to 
the east rift zone. Within the rift zones these vertical dikes are manifested as fissures. A sill-11ke body, the Ulwekehuna laccolith, is exposed in the Kilauea crater. All the exposed Intrusive bodies belong to the Puna volcanic serles and consist of gabbro and a few "exotics" resulting from crystal settling. 5

\subsubsection{Tectonic history}

The Hawailan Island chain is very young by geologic standards. The oldest rocks of the major islands exposed above sea level are believed to have formed during the Pliocene epoch ( 3 to 12 million years ago). On the basis of radioactive age dates and other evidence, the rocks of Oahu and islands further south are believed to be no older than Pleistocene ( 15 thousand to 3 million years old).

The island of Hawail is the youngest of all the islands. It is the only island having a historical record of volcanic activity and the only island considered to be seismically active. All the lava flows of the Island of Hawail have normal magnetic polarities, suggesting that they belong to the Bruhnes paleomagnetic epoch (less than 800 thousand years old).

The rocks of Kllauea and Mauna Loa are the youngest of all. The oldest members of the Hilina volcanic series of Kilauea interfinger with the youngest Ninole series of Mauna Loa. Therefore, the oldest rocks exposed at Kilauea are probably on the order of 100 thousand years. The Puna volcantc series, which overlies the Hilina, is subdivided into two members: 
(1) a prehistoric late Pleistocene member, which in places is capped by sand dunes and (2) an historic member that is still accumulating. Table 2.2 is a record of eruptions on the east rift of Kilauea that have occurred in the historic period.

Table 2.2. Historic eruptions of the east rift of Kilauea, 1750-1969

\begin{tabular}{lccc}
\hline Year & $\begin{array}{c}\text { Duration } \\
\text { (days) }\end{array}$ & $\begin{array}{c}\text { Area } \\
\text { (sq miles) }\end{array}$ & Volume $\left(y d^{3} \times 10^{6}\right.$ ) \\
\hline $1750(7)$ & $?$ & 1.57 & 19.5 \\
$1790(7)$ & $?$ & 3.04 & 37.7 \\
$1840^{\circ}$ & 26 & 6.60 & 281.0 \\
1884 & 1 & At sea & $?$ \\
1923 & 1 & 0.20 & 0.1 \\
$1955^{b}$ & 88 & 6.1 & 120.0 \\
$1960^{\circ}$ & 36 & 4.1 & 155 \\
1961 & 3 & 0.3 & 3.0 \\
1962 & 2 & 0.02 & 0.4 \\
1963 & 3 & 0.06 & 1.1 \\
1963 & 2 & 1.3 & 9.1 \\
1965 & 10 & 3.0 & 23.0 \\
1965 & 1 & 0.23 & 1.2 \\
1968 & 5 & 0.01 & 0.1 \\
1968 & 15 & 0.8 & 9.0 \\
1969 & 6 & 2.3 & 22.0 \\
$1969^{d}$ & Mav $24-$ Nov. 20 & 4.8 & 71.0 \\
& & & \\
\hline
\end{tabular}

Broad zone along the east rift, including the well site.

Including the immediate area of the well site.

4 miles east of well site.

Still in progress on date of recording; this eruption occurred 10 to 15 miles west of the well site.

Source: G. A. Macdonald and A. T. Abbott, Volcanoes in the Sea - the Geology of Haweii, University of Hawaii Press, Honolulu, 1970.

Fault movement is also still taking place. Many Puna lava flows of recent age cascaded over older fault scarps, but were themselves displaced by subsequent movement. 


\subsubsection{Seismicity}

The Island of Hawaii is the only island in the Hawailan chain that could be characterized as a selsmically active region. ${ }^{4}$ Although earthquakes occasionally occur on the other islands, the great majority take plac? on Hawaii; most of the earthquakes are small and do little or no damage.

The U.S. National Oceanic and Atmospheric Administration ${ }^{6}$ provides a more or less complete list of earthquakes (Modified Mercalll Intensity $\geqslant v$ ) in the Hawailan Islands, beginning with a major earthquake in 1868 and extending through 1970. Between 1834 and 1868, two other earthquakes are also listed by NOAA. The geologic-geographic distribution of these earthquakes is shown in Table 2.3 .

Although there is no published record of earthquakes in Hawail for the first half of the 1970 s, a particularly strong earthquake ( 7.2 on the Richter scale) occurred imediately offshore from Kaimu Beach on the south coast of the Puna district in November 1975. If it had occurred on land, it would have been capable of causing near total destruction In the epicentral area and extensive damage in Imediately adjacent regions.

The earthquake of 1868 , which also occurred near the south coast of the Island of Hawail, had an estimated intensity (Modified Mercall1) $>\mathrm{X}$. This earthquake caused nearly complete destruction of wooden structures at Kelawa, Punaliu, and NInole, located near the terminus of the southwest 
Table 2.3. Distribution of earthquakes, 1834-1970

\begin{tabular}{cc}
\hline Location & Number \\
\hline Hawaiian Island Chain & 102 \\
Island of Hawaii & 85 \\
Volcanoes and associated rifts & 47 \\
Kilauea & 21 \\
Mauna Loa & 20 \\
Hualalai & 6 \\
Faults subparallel to rifts & 6 \\
Kaoiki (Mauna Loa) & 5 \\
Kealakekua (Mauna Loa) & 1 \\
South and south coast & 2 \\
Other locales & 12 \\
Unidentified by locale & 18 \\
Other islands & 13 \\
Unidentified by locale & 4 \\
\hline
\end{tabular}

- There may be minor errors in the classification due to uncertainty of epicenter locations.

- Uncertain association with volcanoes, rift zones, and subparallel fault systems. For example, two earthquakes have been identified as having occurred at Hilo, on the east coast. They could have been placed in either the Mauna Kea or Mauna Loa rift zones. Perhaps, on the other hand, they are unrelated to volcanism.

Source: J. L. Coffman and C. A. von Hake, eds., Earthquake History of the U.S., U.S. National Oceanic and Atmospheric Administration, U.S. Dept. of Commerce, U.S. Government Printing Office, Washington, D.C., 1973.

rift zone of Kilauea, and landslides beyond Hilo on the east coast as far as Waiplo and Hamakua. Fissures extended along the southwest rift zone from Pahalo to Kilauea. At Kohuku, volcanic eruptions accompanied the opening of a $4.8-\mathrm{km}-$ long (3-mile) fissure. Ground swells of 0.3 to $0.6 \mathrm{~m}$ ( 1 to $2 \mathrm{ft}$ ) occurred, and a Tsunami wave exceeding $18 \mathrm{~m}(60 \mathrm{ft})$ in height struck the $\mathrm{Ka}$ 'u-Puna coast, sweeping structures off the beach. 4,6

The year 1868 was also a big year for volcanic eruptions; it is the only historical period in which Mauna Loa and Kilauea erupted simultaneously. 5 
In addition to the fissure eruption on the southwest rift zone of Kilauea, an offshore eruption occurred on the seaward extension of the east rift zone.

At least 5 intermediate (Mercalli VI and VII) and 16 minor (Mercalli V) intensity earthquakes have been experienced at $\mathrm{Kilauea}$ and its associated rift zones since 1834. All the intermediate shocks were capable of causing light to moderate damage to wooden structures. Three of the intermediate shocks took place along the east rift zone of Kilauea in the Puna district; two occurred a few months before the extensive volcanic eruptions of 1955, and the third occurred during that eruption. 6

\subsubsection{Mineral resources}

The mineral deposits of the Puna district are quite limited. Cinders and pumice are the only known exploitable resources in the east rift zone of Kilauea. Widely distributed over all the islands, they are used for raising orchids, weed control around flower gardens, and decorative purposes. Semiprecious gems have been found locally. Pele's tears (black, opaque obsidian droplets) are abundant around Halemaumau on Kilauea. They are produced from broken ends of glass filaments as they drift away from fire fountains. Because fire fountains have been seen during eruptions on the rift zone, Pele's tears might be present in the Puna district. Most of the Pele's tears sold in Hawail, however, are artificial. Hawailan olivines (peridot) are found in the 1840 lava flows of the Puna district; however, they are too small to be of gem 
quality, and therefore peridot is imported from the U.S. mainland for sale in local jewelry stores. 5

Industrial minerals are also limited. A large sulfur deposit occurs along the rim of Kilauea caldera, and traces of sulfur have been found along steam vents of Kilauea. Sulfur has not been mined comercially in Hawail. Its wide availability as a by-product of petroleum production in other parts of the world and in salt domes of the LouisianaTexas Gulf Coast probably precludes its development in Hawail except possibly for local use. Titaniferrous magnetite ( $\mathrm{TiFe}_{2} \mathrm{O}_{4}$ ) occurs in Hawailan basalts, but as yet no effective means of separating the titanium has been achieved. Ilmenite $\left(\mathrm{FeT1O_{3 }}\right)$ and rutile $\left(\mathrm{T} 1 \mathrm{O}_{2}\right)$ are the two principal sources of titanium. Although these two ore minerals have not been reported on Hawail, ilmenite is commonly associated with magnetite. It is usually found in large quantities only in massive intrusive peridotite bodies. Although peridotite is comonly found as local inclusions in the lavas of Hawail, no extensive peridotite bodies are known to occur there. The absence of large bodies of peridotite is to be expected in view of the accepted theory of formation of a mantle plume. The major mineral constituents of peridotite are olivine and pyroxene, and the common accessory minerals are magnetite, titaniferrous magnetite, and ilmenite. These minerals are heavy and have high melting points. As partial melting takes place, a mantle plume forms and peridotite sinks to the bottom, thus forming the upper mantle buried deep beneath the Hawailan Island chain. 
Large deposits of low-grade bauxite (aluminum) ore were found in posterosional, deeply weathered basalts on the islands of Kauai and Maui.5 The high cost of power, distance from markets, and government restrictions were among the disadvantages that forced abandonment of mining development there. Even if bauxite mining should become attractive in the future, Kilauea and its associated rift zones would be unlikely sites for development. Natural bauxite enrichment requires a long period of deep weathering. Since the Kilauea volcanics are the youngest rocks of the entire Hawaiian Island chain, very little ore concentration could have taken place there.

Water is the only valuable wineral resource that wight be disturbed by the test well in Puna district.

\subsubsection{Known geothermal resources}

Although a number of potential geothermal resource sites probably exist In the various rift zones of the Island of Hawail, the only known geothermal resource area is the site for which this assessment is being prepared. The Pahoa site of the east rift zone of Kllauea was selected on the basis of a geophysical (self-potential) anomaly together with other evidence. Two other self-potential anomalies were also located on the east rift of Kilauea, and although the presence of a geothermal resource has not been demonstrated, the potential exists. 7 Research scientists involved in this project belleve that the Pahoa site offers the best chance of recovering geothermal fluid. 
Only a few holes have been drilled to test for the presence of geothermal resources on Hawaif. Several shallow test holes were drilled in 1962 in the Puna district by Hawail Thermal Power Company. One hole reached a bottom-hole temperature of $102^{\circ} \mathrm{C}\left(215^{\circ} \mathrm{F}\right)$, but very little steam was produced. ${ }^{7}$ In 1973 a research hole was drilled to a depth of $1262 \mathrm{~m}$ (4140 ft) beneath the sumit of Kllauea. The highest temperature recorded in this hole was $137^{\circ} \mathrm{C}\left(279^{\circ} \mathrm{F}\right)$. Rock is fully saturated with water from the bottom of the hole [160 m (525 ft) below sea level] to $500 \mathrm{~m}$ (1640 ft) above sea level. Electric well logs suggest that the water is slightly more saline than seawater. 8

\subsection{HYDROLOGY}

\subsubsection{Groundwater}

Groundwater resources in Hawali's Puna district occur in two major forms. A portion of the water is confined within porous compartments bounded by relatively impermeable dikes. These dikes are commonly vertical or steeply dipping and are generally associated with rift zones. However, the major freshwater source is basal water. It occurs as a broad lensshaped groundwater body, commonly called a Ghyben-Herzberg lens, and floats on the denser salt water beneath the island. In the Puna district, the basal water is unconfined and occurs within the underlying basaltic reservolrs as fresh or bracklsh water.

Eight sites have been used to evaluate the groundwater quality of Puna. The locations of each well and spring are illustrated in Fig. 2.4; 


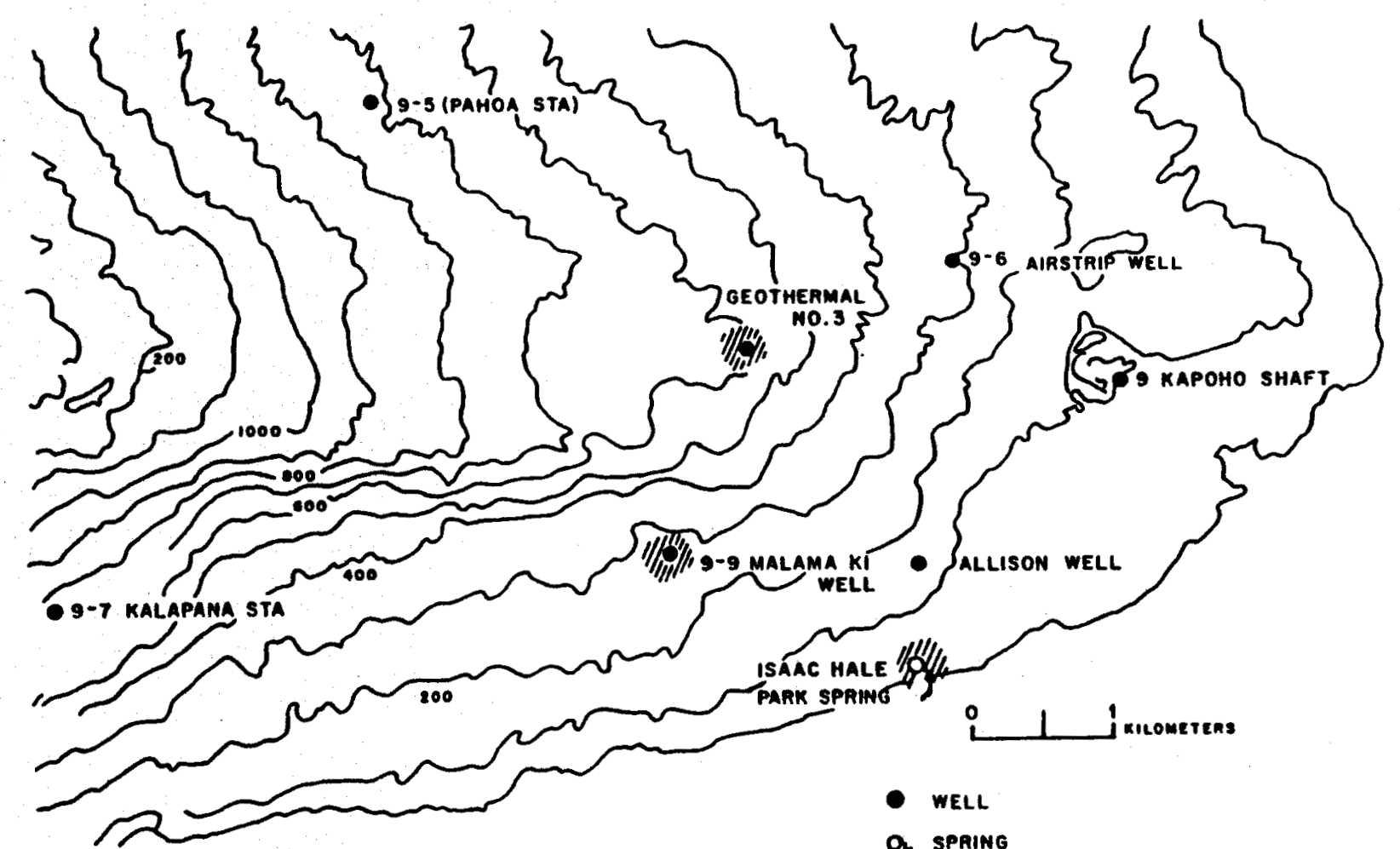

Fig. 2.4. Location of sampled wells and spring, Puna, Hawai1. Source: University of Hawail, Environmental Baseline Study for Geothermal Development in Puna, Howaii, Hawail Geothermal Project, Honolulu, September 1976, F1g. 2, p. 14. 
Table 2.4 lists the chemical analyses of each site. These samples are predominantly a sodium-bicarbonate type; wells 9-5 and 9-7 may be regarded as representative. Well shaft 9 is anomalously high in bicarbonate ion for reasons presently unknown.

Chloride content in each sample is generally high for basal water due to local conditions. Near the coast, groundwater wixes with the underlying salt water where the basal lens thins out and is readily disturbed by tides or active pumping. Local salination therefore increases as distance from the coast decreases. Sites close to shore are commonly brackish, as exemplified by the Isaac Hale Spring. Brackish waters may also occur further inland when heating induces the upward movement of salt water and subsequent mixing. These conditions yield the relatively high salinities displayed at we1l $9-9$ and geothermal drill hole No. 3.

In addition to changes in salinity, an increase in temperature may also affect specific ion exchange reactions. At temperatures greater than $30^{\circ} \mathrm{C}\left(86^{\circ} \mathrm{F}\right)$, the basal water exhibits an increased interaction with the surrounding basalts. This temperature-dependent reaction creates a larger chloride concentration, excessive amounts of potassium and silica, and a decrease in magnesium.

Groundwater collform and fecal collform analyses indicate generally pollution-free reservoirs and are listed in Table 2.5. The high collform concentrations in the Allison well are believed to be associated with local contamination during sampling. 
Toble 2.4. Chemical data, groundwater and reinweter, Puna. Hewaii

\begin{tabular}{|c|c|c|c|c|c|c|c|c|c|c|c|c|c|c|c|}
\hline \multirow{2}{*}{$\begin{array}{l}\text { Old } \\
\text { number }\end{array}$} & \multirow{2}{*}{$\begin{array}{c}\text { Stute } \\
\text { number }\end{array}$} & \multirow{2}{*}{ Nome } & \multirow{2}{*}{ Date } & \multirow{2}{*}{$\begin{array}{l}\text { Temperature } \\
\mathrm{I}^{\circ} \mathrm{Cl}\end{array}$} & \multirow{2}{*}{$\rho \mathrm{H}$} & \multicolumn{10}{|c|}{ Concentration (mg/iter) } \\
\hline & & & & & & No & K & C. & Mg & Cl & $\mathrm{HCO}_{3}$ & $\mathrm{SO}_{4}$ & $\mathrm{SiO}_{2}$ & $N^{2}$ & $\mathbf{P}$ \\
\hline $9-5$ & 2986-01 & Pahoa Station & $1-6.75$ & & 7.30 & 36.0 & 2.72 & 1.58 & 2.7 & 13.5 & 48 & 21.1 & 50.0 & 0.252 & 0.078 \\
\hline 8.7 & 2487.01 & Kalapana Station & 1.6 .75 & 28.5 & 7.68 & 89.6 & 5.20 & 5.30 & 6.6 & 132.2 & 38 & 37.2 & 44.5 & 0.070 & 0.056 \\
\hline 9 & $3080-02$ & Kepoho shaft & 1.6.75 & 25.5 & 7.80 & 85.8 & 6.60 & 42.4 & 37 & 16.9 & 372 & 20 & 53.6 & 0.378 & 0.233 \\
\hline \multirow[t]{3}{*}{$9-6$} & $3081-01$ & Airstrip mell & 1.6 .75 & 33.0 & 7.42 & 238 & 13.6 & 23.0 & 28 & 303.5 & 48 & 204 & 71.3 & 0.014 & 0.040 \\
\hline & 2881 & Allison wefl & 1.7 .75 & 37.5 & 7.35 & 216 & 10.8 & 13.4 & 15 & 281 & 132 & 69.2 & 24.1 & $>14$ & $<0.002$ \\
\hline & & $\begin{array}{l}\text { Irave Male Park } \\
\text { Spring. }\end{array}$ & 1.7 .75 & 36.0 & 7.75 & 2020 & 86.0 & 32.4 & 200 & 3534 & 56 & 507 & 81.5 & 1.218 & 0.016 \\
\hline \multirow[t]{3}{*}{ 8.9 } & $2783-01$ & Matama Ki well & 1.7 .75 & 52.3 & 7.02 & 2105 & 109 & 66.8 & 210 & 3811 & 144 & 471 & 100.7 & 0.280 & 0.006 \\
\hline & & Geothermal No. 3 & 1.7 .75 & 93.0 & 6.85 & 2050 & 190 & 76.8 & 52 & 3274 & 30 & 314 & 96.6 & 0.003 & 0.006 \\
\hline & & $\begin{array}{l}\text { Rain at Kalopena } \\
\text { Station }\end{array}$ & $1.6-75$ & & & 4.5 & 0.25 & 0.25 & 0.75 & 7.2 & & $\sim 2.5$ & 0 & 0.024 & $<0.002$ \\
\hline
\end{tabular}

- $\mathrm{NO}_{2}$ and $\mathrm{NO}_{3}$ is $\mathrm{N}$.

Source: University of Hawaii, Environmental Baseline Study for Geothermel Development in Puns, Howaii, Honolulu, September 1976. 
Table 2.5. Microbiological quality of groundwater, Puna, Hawaii

\begin{tabular}{|c|c|c|c|c|c|c|}
\hline $\begin{array}{l}\text { Well/shaft } \\
\text { number }\end{array}$ & $\begin{array}{c}\text { State } \\
\text { number }\end{array}$ & Name & $\begin{array}{l}\text { Date of } \\
\text { sample }\end{array}$ & $\begin{array}{l}\text { Coliform MPN } \\
\text { (No. per } 100 \mathrm{ml} \text { ) }\end{array}$ & $\begin{array}{l}\text { Fecal coliform MPN } \\
\text { (No. per } 100 \mathrm{ml} \text { ) }\end{array}$ & Remark \\
\hline 9.5 & 2986 & Pahoa & $1-6.75$ & $<3$ & $<3$ & $\begin{array}{l}\text { Unchlorinated } \\
\text { sample }\end{array}$ \\
\hline $9-7$ & $2487-01$ & Kalapana & $1 \cdot 6 \cdot 75$ & $<3$ & $<3$ & $\begin{array}{l}\text { Unchlorinated } \\
\text { sample }\end{array}$ \\
\hline 9 & $3080-02$ & Kapoho shaft & 1.6 .75 & 460 & $<3$ & . \\
\hline 9.6 & 3081 & Airstrip & $1-6.75$ & $<3$ & $<3$ & \\
\hline \multirow[t]{3}{*}{$9-9$} & 2783 & Malama Ki & $\mathbf{1} \cdot 7.75$ & $<3$ & $<3$ & \\
\hline & & $\begin{array}{l}\text { Isaac Hale } \\
\text { Beach Park. } \\
\text { hot spring water }\end{array}$ & 1.7 .75 & 1.500 & 7 & \\
\hline & 2881 & Allison & 1.7 .75 & $\geqslant 24,000$ & 93 & $\begin{array}{l}\text { Well bottom } \\
\text { mud in sample }\end{array}$ \\
\hline
\end{tabular}

Source: University of Hawaii, Environmental Baseline Study for Geothermal Development in Puna, Hawaii, Honolulu, September 1976. 
At present, the salinity as a function of depth for the geothermal well is unknown. Water samples that were taken from the top of the hole durIng a short flow test yielded a salinity of $2322 \mathrm{ppm}$ (Ref. 9). Analyses of the deep water samples with a pressure bomb compared favorably with those from the flow test; however, these results were considered suspect because of the high temperature encountered, which caused contamination of the pressure bomb as it was withdrawn from the hole.

If reliable conclusions can be drawn from the chemical analyses of the water samples, they suggest that either (1) the base of the GhybenHerzberg lens is very deep or (2) mixing of salt and fresh water has taken place, locally elfminating the lens. The low concentration of total dissolved solids (2322 ppm) in well samples (far less than the 35,000 ppm TDS of normal seawater) may be the result of (1) convective circulation of hot seawater mixing with fresh water (cold seawater will not mix with the overlying fresh water because of its higher density) or (2) an abnormally shallow water table. The actual elevation of the water table at the well is not known, but it is probably more than $90 \mathrm{~m}$ (300 ft) above sea level. Th1s suggests that the bottom of the hole [1768 $\mathrm{m}$ ( $5800 \mathrm{ft}$ ) below sea level] is well above the bottom of the Ghyben-Herzberg lens.

Phreatic explosions during eruptions in the eastern part of the Puna district and near Kilauea suggest that water is indeed trapped at shallow depth. Keller ${ }^{8}$ believes that the water table 11 es $500 \mathrm{~m}$ (1640 ft) above sea level at Kilauea. Phreatic explosions are caused by large quantities 
of water being flashed to steam at relatively shallow depth. Although basal water could conceivably contribute to phreatic explosions at east Puna, it could not be the case at the higher elevations closer to Kilauea. Many phreatic explosions are almost certainly caused by water trapped at shallow depth in dike complexes.

\section{5 .2 Surface water}

Surface water sources in the Puna district are nearly nonexistent except for isolated ponds, springs, or reservoirs. Most of the area consists of undissected upland displaying few, if any, established stream channels. Streams are intermittent due to limited watersheds and the high permeability of the basaltic soil and rock.

\subsection{LAND USE}

Land use on the Island of Hawail is about evenly divided between agricultural and forested land (see Table 2.6). The third-ranking category is recreational, primarily because of the large Volcanoes National Park surrounding Kilauea (FIg. 2.2).

The Puna district is primarily forest (commercial and noncomercial open land). Other large land categories are conservation (forest reserves). and agriculture. The soils of Puna district are well-drained, relatively young soils that have developed on lava (mollisols) and weakly developed solls that have developed on volcanic ash (inceptisols). Therefore, the potential for large-scale, highly productive agriculture is limited. 
Table 2.6. Land use - Island of Hawaii

\begin{tabular}{lr}
\hline \multicolumn{1}{c}{ Land use } & $\begin{array}{c}\text { Land area } \\
\text { (acres) }\end{array}$ \\
\hline Sugar cane & 114,775 \\
Vegetable & 1,916 \\
Orchard & 21,529 \\
Grazing & 794,629 \\
Dairy & 3 \\
Poultry & 7 \\
Idle agriculture & 0 \\
Forest & 197,823 \\
Forest reserve & 710,260 \\
Recreation & 794 \\
Game management & 19,288 \\
National park & 211,688 \\
Urban & \\
Undeveloped residential & 74,429 \\
Developed & 12,146 \\
Pali and barren land & 421,945 \\
Water & 101 \\
$\quad$ Total & $2,584,320$ \\
\hline
\end{tabular}

Source: University of Hawaii, Atlas of Hawaii, Department of Geography, University of Hawaii Press, Honolulu, 1974.

Table 2.7 lists existing land use acreage in the Puna district. Open land dominates (75\% of the land area) In this category. Recreation includes part of the Volcanoes National Park and state land.

Agriculture is the primary means of existence for Puna residents. A summary of agricultural acreage and crop value (for recent years) in the Puna district is shown in Table 2.8. It should be noted that these agricultural acreages generally are not located in areas of recent lava flows, whereas the site is. 
Table 2.7. Existing land use in Puna district

\begin{tabular}{lr}
\hline \multicolumn{1}{c}{ Existing land use } & Land area (acres) \\
\hline Residential & $2,219.3$ \\
Manufacturing & 32.1 \\
Nonmanufacturing & 391.6 \\
Retail & 28.8 \\
Services & 124.1 \\
Social & 42.2 \\
Recreation & $52,095.1$ \\
Agriculture & $27,748.1$ \\
Transportation (non-road) & 0.0 \\
Open (forest) & $237,370.3$ \\
$\quad$ Total & $320,051.6$ \\
$\quad$ (not including roads) & \\
\hline
\end{tabular}

Source: Hawaii County Research and Development Department, unpublished data, 1976.

Table 2.8. Summary of acreage for major agricultural activities in Puna

\begin{tabular}{lcr}
\hline \multicolumn{1}{c}{ Crop } & Planted acreage & \multicolumn{1}{c}{ Value (\$) } \\
\hline Sugar & 15,300 & $32,600,000(1974)$ \\
Papaya & 1,840 & $4,890,000(1975)$ \\
Macadamia & 2,450 & $855,000(1974)$ \\
Anthurium & 247 & $237,000(1974)$ \\
Other flowers & $168($ County) & \\
Truck farming & 171 & \\
Guava & 75 & \\
Orange and tangerine & 58 & \\
\end{tabular}

- 1974 data based on County of Hawaii Research and Development Department Testimony to the Civil Aeronautics Board.

Source: County of Hawail Research and Development Department and State of Hawaii Department of Agriculture, unpublished data, 1976. 


\subsection{WATER USE}

Surface water in the area of the site is nearly nonexistent. Several wells exist in the vicinity (Sect. 2.5.1). Well water tends to be brackish basal water (Fig. 2.4 and Table 2.4). The Pahoa Station records quite fresh water. However, in general, groundwater in the area is not potable or good for agricultural uses.

\subsection{CLIMATOLOGY}

The climate of Hawail's Puna district is typified by mild equable temperatures, moderate humidities, northeasterly trade winds, large differences in precipitation within short distances, and infrequent severe storms.

Because Puna is located within the tropics, the length of day remains relatively uniform throughout the year. Solar radiation and daily temperatures therefore display only slight variation from season to season. Hawail's weather is further modified by the surrounding ocean. Because water warms and cools more slowly than does alr, it regulates the temperature and humidity of air masses prior to their arrival at Hawail and moderates any harsh qualities the air might otherwise display.

Climatic conditions are further influenced by Hawail's wind patterns and local topography. Hawail's wind and storm patterns are dominated by the northeasterly trade winds associated with the nearby Pacific High. When these northeasterlies or other air masses reach the island, 
the topographic diversity frequently induces precipitation and local storms as the cooling air travels up and over the island. During nontrade-wind conditions, weather patterns fall under the influence of effects from low-pressure areas, other high-pressure zones, cold fronts, or diurnal heating.

\subsubsection{Temperature and humidity}

Temperatures in Puna are mild and display only slight annual variation. Throughout the year, nearby Hilo experiences a range of only $2.7^{\circ} \mathrm{C}\left(5^{\circ} \mathrm{F}\right)$ between monthly means. Averages vary from $21.7^{\circ} \mathrm{C}\left(71^{\circ} \mathrm{F}\right)$ in January to $24.4^{\circ} \mathrm{C}\left(76^{\circ} \mathrm{F}\right)$ in August. 10 Annual temperature ranges in and around the Puna district are listed in Table 2.9.

Table 2.9. Temperature ranges in and around Puna district

\begin{tabular}{lccc}
\hline Station & $\begin{array}{c}\text { Elevation above } \\
\text { sea level }(\mathrm{ft})\end{array}$ & $\begin{array}{c}\text { Mean January } \\
\text { temperature }\end{array}\left(^{\circ} \mathrm{F}\right)$ & $\begin{array}{c}\text { Mean August } \\
\text { temperature }\left(^{\circ} \mathrm{F} \text { ) }\right.\end{array}$ \\
\hline Hilo & 40 & 71 & 76 \\
Mountain View & 1530 & 65 & 70 \\
Hawaii National & 3971 & 58 & 64 \\
Park & & & \\
\hline
\end{tabular}

Source: D. Blumenstock and S. Price, "The Climate of Hawaii," Climates of the States, vol. 2. Water Information Center, Inc., Port Washington, N.Y., 1974.

Dally temperatures along Puna's northeast coast commonly fluctuate by 4.4 to $8.3^{\circ} \mathrm{C}\left(8\right.$ to $\left.15^{\circ} \mathrm{F}\right)$ between early morning and late afternoon extremes. August and September bring the warmest temperatures, which occasionally reach $32.2^{\circ} \mathrm{C}\left(0^{\circ} \mathrm{F}\right)$, but rarely exceed $35.0^{\circ} \mathrm{C}\left(95^{\circ} \mathrm{F}\right)$. February and March are the coolest months, with temperatures only rarely falling to around. $10^{\circ} \mathrm{C}\left(50^{\circ} \mathrm{F}\right) .10$ 
Humidity is generally moderate to high in this area, ranging from 65 to $90 \%$ (Ref. 1). Under trade wind conditions, the moist air below $1220 \mathrm{~m}$ (4000 ft) is confined under a dry, high-temperature inversion layer. Occurring 50 to $70 \%$ of the time, this layer suppresses most vertical air movement and restricts cloud formation to the lower layers. 10

Windward areas such as Puna tend to be cloudier during the sumer when trade winds and trade wind clouds prevail. In windward lowland areas similar to the drill site, the sky is cloudy ( $8 / 10$ or more cloud cover) 40 to $60 \%$ of the time during daylight hours and clear $(3 / 10$ or less cloud cover) 15 to $20 \%$ of the time. 10

\subsubsection{Wind characteristics}

Wind patterns at the drill site are dominated by trade winds created by the Pacific High northeast of Hawail. Strongest during the afternoons, the trade winds are dominant during $90 \%$ of the summer and $50 \%$ of the winter. These winds come out of the northeast 80 to $95 \%$ of the time, frequently exceeding $19 \mathrm{~km} / \mathrm{hr}$ (12 mph). 1 During the absence of trades, winds become light and variable and may yield to diurnal heating, thus producing onshore sea breezes during the day and offshore land breezes at night. This regime is enhanced by the daytime upslope and nighttime downslope wind patterns created by nearby mountains.

Between October and April, Hawail may be subjected to the southerly winds of Kona (leeward) storms. In addition, migrating cold fronts 
may induce patterns typified by the southwesterly winds that precede and the northerly winds that follow the fronts. On occasion, the storm and trade winds may be severe enough to damage local vegetation or structures.

\subsubsection{Precipitation}

Rainfall in Hawail consists primarily of orographic (mountain-caused) rains due to moist trade winds encountering the island slopes. Also, convective showers typified by large cumulus clouds and localized brief showers may occur over the intertor on calm sunny days. Heaviest rains generally occur during the winter (October to April) season. These rains may drop $7.6 \mathrm{~cm}$ ( $3 \mathrm{in.}$ ) or more in a single hour and, during record rains, up to $27.9 \mathrm{~cm}$ (11 in.) in an hour. 1 Droughts, however, are not uncommon, particularly when the winter storms fail.

Average annual rains in Puna range from $190 \mathrm{~cm}(75 \mathrm{ln.})$ along the southeast coast to 318 to $381 \mathrm{~cm}(125$ to $150 \mathrm{in.})$ along the northeast coast to $508 \mathrm{~cm}$ (200 in.) along Puna's northwest margin. Located at $183 \mathrm{~m}$ (600 ft) above sea level, geothermal well No. 3 recelves an annual precipitation of about $318 \mathrm{~cm}$ (125 in.).1 At nearby Hilo, elevated

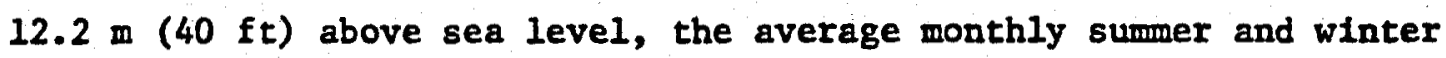
rainfall is $24.08 \mathrm{~cm}(9.48 \mathrm{ln}$.) and $33.81 \mathrm{~cm}(13.31 \mathrm{in.}$ ) respectively. The wettest month is March, which has an average of $39.24 \mathrm{~cm}$ (15.45 in.), and the driest is June, which has an average of $17.27 \mathrm{~cm}(6.80 \mathrm{in})$. 
may induce patterns typified by the southwesterly winds that precede and the northerly winds that follow the fronts. On occasion, the storm and trade winds may be severe enough to damage local vegetation or structures.

\subsubsection{Precipitation}

Rainfall in Hawaii consists primarily of orographic (mountain-caused) rains due to moist trade winds encountering the island slopes. Also, convective showers typified by large cumulus clouds and localized brief showers may occur over the interior on calm sunny days. Heaviest rains generally occur during the winter (October to April) season. These rains may drop $7.6 \mathrm{~cm}$ ( $3 \mathrm{in.}$ ) or more in a single hour and, during record rains, up to $27.9 \mathrm{~cm}$ (ll in.) in an hour.l Droughts, however, are not uncomon, particularly when the winter storms fail.

Average annual rains in Puna range from $190 \mathrm{~cm}$ (75 in.) along the southeast coast to 318 to $381 \mathrm{~cm}$ (125 to $150 \mathrm{in.})$ along the northeast coast to $508 \mathrm{~cm}$ (200 in.) along Puna's northwest margin. Located at $183 \mathrm{~m}(600 \mathrm{ft})$ above sea level, geothermal well No. 3 receives an annual precipitation of about $318 \mathrm{~cm}(125 \mathrm{in.}) .^{1}$ At nearby H1lo, elevated $12.2 \mathrm{~m}$ ( $40 \mathrm{ft}$ ) above sea level, the average monthly summer and winter rainfall is $24.08 \mathrm{~cm}(9.48 \mathrm{in.})$ and $33.81 \mathrm{~cm}$ (13.31 in.) respectively. The wettest month 1s March, which has an average of $39.24 \mathrm{~cm}$ (15.45 in.), and the driest is June, which has an average of $17.27 \mathrm{~cm}(6.80 \mathrm{in.}) .10$ 


\subsubsection{Storms and extreme weather}

Although storms are frequent in Hawail, they are of ten brief and only rarely severe. Most storms consist of light to moderate trade wind showers, although local areas may receive strong winds and heavy rainfall.

Trade wind conditions are less dominant during the winter months, as evidenced by more frequent cloudiness, rainfall, and storm activity. Kona storms are low-pressure areas which develop northwest of Hawaii and move eastward. These areas induce moist southerly winds and are indicative of bad weather in Hawail. Intense localized storms may result, occasionally with periods of thunder and lightning. Cold fronts may also reach the Puna district during non-trade-wind conditions, causing severe storms, strong winds, intense localized rains, and sudden drops in temperature. Although funnel clouds may occur under a variety of conditions, they are often associated with cold fronts. Averaging 20 sitings per year in and around the Islands, most funnels occur as waterspouts that may drift onshore and cause local damage. Tornadoes are also known to develop over the interior of the Islands. Severe weather may be attributed to low-pressure areas In the upper atmosphere. Such weather resembles Kona storms and often creates towering cumulus clouds, thunderstorms, widespread and torrential rains, and winds from almost any direction.

Not limited to winter months, tropical storms are most likely to occur from July to December. Typlfied by Intense winds, only a few reach 
hurricane intensity $-118 \mathrm{~km} / \mathrm{hr}(74 \mathrm{mph})$. Only four true hurricanes have affected Hawail in a 63-year period. However, a tropical storm of less intensity may be expected to affect the Islands every one or two years.

\subsubsection{Air quality}

The air over Hawait's Puna district is clean and low in pollution. Frequent trade winds readily disperse most particulates and chemical contaminants. At the present time, air quality data consist of mercury determinations on samples from the drill site, Hilo, and the Sulfur Banks; these values are listed in Table 2.10. The drill site air sample yielded nearly one-half of the Sulfur Banks mercury content. However, this may be only a transitory value due to wind movement and temperature gradient effects.

Table 2.10. Air values for marcury, Island of Hawaii, May 22, 1975

\begin{tabular}{lc}
\hline \multicolumn{1}{c}{ Location } & Measurement $\left(\mu \mathrm{m} \mathrm{m}^{-3}\right)$ \\
\hline Drill site air & $1.11 \pm 0.58$ \\
Hilo air & $0.44 \pm 0.27$ \\
Sulfur Banks, Hawaii Volcanoes National Park air & $2.6 \pm 0.51$ \\
\hline
\end{tabular}

Source: University of Hawaii, Environmental Baseline Study for Geothermal Development in Puna, Hawaii, Hawaii Geothermal Project, Honolulu, September 1976. 


\subsection{ECOLOGY}

The Hawailan Islands are removed from mainland plant and animal populations by 3220 to $6440 \mathrm{~km}$ (2000 to $4000 \mathrm{miles})$ of ocean. The rate at which small groups of gravid females, propagules, or sexually compatible pairs reach the islands from mainland stocks is extremely low. Only certain types of organisms (i.e., those that fly, swim, or float or those that, at some time in their life cycle, are transported along with such organisms) could potentially survive the journey. Even after arrival, success of small populations is rare.11,12 Therefore, the native fauna and flora of Hawaii have developed from a very few successful colonizations.

The successfully colonizing populations have radiated into new habitats and adaptive modes. In time, this has allowed the evolution of unique species and races quite different from their mainland ancestors and, in addition, has allowed diversification and speciation within groups on the islands. ${ }^{11}$ The Hawaiian fauna and flora are therefore unique; many species are found nowhere else.

Since the arrival of western man 200 years ago, two factors have contributed to the decline of native blota - the introduction of exotic species and habitat disturbance. Hundreds of European and Asian plants and antmals have been introduced for agriculture, pest control, exhibition, and various other purposes; many have become established as breeding populations. In so doing, they have replaced native species 
by exerting predation or ampelition pressures for which the endemic species werc not adapted. Western man's encroachment of the islands and his cultivation and Industrialization of large areas have caused significant reduction in habitat. The native biota of the isilunds, as a result, is reduced to small enclaves high on mountain slopes and other areas not amenable to man's activities.

\subsubsection{Flora}

More than 2500 kinds of higher plants occur in the Hawailan Lslands and nowhere else. These plants have evolved from about 275 species of natural immigrants. However, the introduction of exotic plants by man, the grazing of introduced animals, and the destruction of habitat have relegated native plants to remote areas.1

The drill site area is located at an exposed lava flow. Because of this, much of the area is in the early stages of primary succession. The undisturbed part of the lava flow consists of barren lava covered by a dense growth of lichens with scattered small ferns and ohia (Metrosideros collina) saplings, thus typifying the usual succession of plants on lava flows in Hawail.

The basic undisturbed forest in this region consists predominantly of ohla trees, the size of the trees being directly related to the age of the underlying lava flow. Hence, most of the trees are of small to medium height, although there are apparent kipukas in which the trees 
reach to about $30 \mathrm{~m}(100 \mathrm{ft})$ in height. The ground cover under and around the ohia trees consists largely of false staghorn fern (Dicranopteris linearis) with several species of orchids scattered throughout; infrequent treeferns (Cibotium sp.) occur in areas with the larger trees. The ieie vine (Freycinetia arborea) is widely distributed in areas with larger ohia trees. This vegetation is typical of that found on lava flows of no great age.

In disturbed areas, however, the vegetation consists predominantly of introduced trees, shrubs, vines, and grasses. Such exotic vegetation is found along roads, in the vicinity of Lava Tree State Park, and in most areas downslope of the drilling site. Exotic vegetation along the roads and trails consists of such plants as mango (Mangifera indica), papaya (Carica sp.), guava (Psidium guajava), bamboo (Bambusa spp.), kukui (Aleurites moluccana), sugarcane (Sacchamm officinamm), bana (Musa sp.), Indian pluchea (Pluchea indica), Jamaica vervain (Stachytarpheta jomaicensis), and sensitive plant (Mimosa pudica). A plantation of Norfolk Island pines (Araucara excelsa) occurs between Lava Tree State Park and the drilling site, and there are groves of albizia (Albizia falcataria) along the road and at the park. An even wider variety of exotic plants is found in and around the park, whose entrance is $1.8 \mathrm{~km}$ ( 1.1 wile) north of the drilling site.

\subsubsection{Fauna}

The only mammals native to the Big Island are the Hawailan hoary bat (Lasiurus cinereus semotus) and the Hawailan monk seal (Monaccus 
schauinslandi). The bat is listed as endangered and the seal as threatened by the U.S. Department of Interior. 13 Only the bat potentially exists in the area considered in this assessment (Sect. 2.9.3). The hoary bat is solitary and roosts in trees and shrubs; the principal breeding population is on the island of Hawail. The reason for the bat's decline is apparenty loss of habitat due to removal of sheltering tree growth. The domestic dog (Canis) and pig (Sus) and a commensal rat (Rattus) accompanied the Polynesians and became assimilated with the native fauna.

Domesticated mammals such as European rabbits, house cats, dogs, cattle, goats, sheep, donkeys, and pigs have been brought by western man and have established feral populations. ${ }^{1}$ The large herbivores have caused the destruction of much of Hawail's lowland forests, elimination of many species of plants, and destruction of habitat for endemic animals. Feral cats and dogs prey on birds and small mamals.

Wild mamals have been introduced to the 1slands as well. Notable among these is the Indian mongoose (Herpestes auropunctatus), which was introduced for rat control. Instead, the mongoose has fed extensively on ground-nesting birds, causing decline and extinction of many bird populations.

Land birds of eight families have populated Hawail without known help from man. The hawk, owl, crow (American origin), and 0ld World warbler families (Asian origin) are each represented by one living native species. 
The thrush family (American origin) is represented by two living native species. The 01d World fly catcher family (American origin) is represented by the Elepaio. The honeyeater family (Australian origin) was once represented by five species, but four are now extinct. The one endemic family, the Hawaiian honeycreepers, or Drepanididae, (American origin) is perhaps the world's best example of "adaptive radiation." From a single ancestral species that reached the Hawaiian Islands in the remote past, 22 species and 24 subspecies of honeycreeper evolved on the various islands. Of the 22 species, 8 are now extinct. 14

of the 66 different unique Hawailan land birds that were known during the nineteenth century, about $35 \%$ are now extinct and over $40 \%$ are considered to be rare or endangered.13 The endangered Hawailan birds account for more than half of all the birds listed by the U.S. Bureau of Sport Fisheries and Wildlife. 13

Forty-eight species of birds have been successfully introduced to the islands and now maintain breeding populations. Many of these are associated only with disturbed areas and human activities. Others have successfully invaded lowland areas of the 1slands and have contributed to the decline of native avifauna.

The drilling site and environs is ecologically youthful due to the recent lava flow (Sect. 2.9.1). Because the size of the ohia trees is directly related to the age of the underlying lava flow, most trees are of small to medium height. Although ohia forests provide habitat 
for the majority of endemic forest birds in Hawaii, most of these species are found at higher elevations.

The surrounding habitats are not suitable for endemic birds except for passage. Two species may occasionally be found in the area of the drilling site - the Hawailan hawk (Buteo solitarius) and Hawailan owl (Asio flameus sandwichensis). The Hawailan hawk is listed as rare and endangered by the Department of Interfor ${ }^{13}$ (Sect. 2.9.3) and by the State Department of Land and Natural Resources. Found only on the Island of Hawail, it is a small soaring hawk that feeds on rodents in open forest, agricultural land, and grassland. Its prime habitat appears to be the slopes of Mauna Loa and windward and Kona coasts.

Birds observed in the site area by a noted ornithologist were all introduced species (1.e., spotted dove, melodius laughing thrush, Japanese white-eye, comon myna, house finch, ricebird, and cardinal).15

\subsubsection{Endangered species}

\subsubsection{Plants}

As discussed in Sect. 2.9.1, endemic plant species have been relegated to remote areas and are threatened by the encroachment of agriculture, industrialization, and other activities of man. An unknown number of species have already become extinct. 
The Puna district is not an area of potential endangered plant species. Apparently, the naturally induced disturbance and the history of human use have eliminated rare endemics. Field surveys and consultation with local authorities have failed to reveal any evidence of rare or endangered plant species in the vicinity of the site.

\subsubsection{Animals}

There are 12 land animal species on the Island of Hawail that are 1isted as endangered with extinction by the Federal government. 13 Table 2.11 lists these species and their preferred habitats.

\subsection{COMMUNITY CHARACTERISTICS AND GOVERNMENTAL STRUCTURE}

The residents of Puna are primarily involved with agriculture. Table 2.12 is a sumary of employment statistics for agricultural activities in Puna.

The salfent feature of governmental structure relevant to geothermal development is simplicity; the only unit of government other than the state itself is the county, the County of Hawail. There are no city governments, townships, school districts, or improvement districts, as are typically found on the mainland.

Because of this simple and highly centralized structure, the path of governmental approval for development involving the land is straight and short: (1) Land use is regulated by the state Land Use Comission, 
Table 2.11. Endangered wildlife of the Island of Hawaii

\begin{tabular}{|c|c|c|}
\hline Name & Habitat & Present distribution \\
\hline $\begin{array}{l}\text { Hawaiian dark-rumped petral (uau) } \\
\text { (Pterodroma phaeopygia sandwichensis) }\end{array}$ & $\begin{array}{l}\text { Oceanic, nests on walls of } \\
\text { craters }\end{array}$ & $\begin{array}{l}\text { Flanks of Mauna Kea and Mauna } \\
\text { Loa }\end{array}$ \\
\hline $\begin{array}{l}\text { Hawaiian goose (nene) } \\
\text { (Branta sandvicensis) }\end{array}$ & $\begin{array}{l}\text { Lava flows } 5000-8500 \mathrm{ft} \\
\text { away from water }\end{array}$ & $\begin{array}{l}\text { Slopes of Mauna Loa and Hualalai: } \\
\text { reintroduction on Maui }\end{array}$ \\
\hline $\begin{array}{l}\text { Hawaiian duck (koloa) } \\
\text { (Anas mrvilliana) }\end{array}$ & $\begin{array}{l}\text { Coastal lagoons, marshes, and } \\
\text { mountain streams }\end{array}$ & Reintroduced experimentally \\
\hline $\begin{array}{l}\text { Hawailan hawk (io) } \\
\text { (Berteo solitarius) }\end{array}$ & $\begin{array}{l}\text { Widespread, open forest. } \\
\text { agricultural land, grassland }\end{array}$ & $\begin{array}{l}\text { Slopes of Mauna Loa, } \\
\text { windward and Kona coasts }\end{array}$ \\
\hline $\begin{array}{l}\text { Hawailan coot (alae keokeo) } \\
\text { (Fulica americana alan }\end{array}$ & Ponds and lagoons & Migrates between islands \\
\hline $\begin{array}{l}\text { Hawaiian stilt (aeo) } \\
\text { (Himantopus himantopus Knudseni) }\end{array}$ & Ponds, lagoons, marshes & Coastal shoreline \\
\hline $\begin{array}{l}\text { Hawaitan crow (aiala) } \\
\text { (Comis tropicus) }\end{array}$ & $\begin{array}{l}1000-8000 \mathrm{ft} \text {, forested and } \\
\text { ranching areas }\end{array}$ & $\begin{array}{l}\text { Higher elevations on north and } \\
\text { south Kona and Kau districts }\end{array}$ \\
\hline Akiapolaau (Hemignathus wilsoni) & $\begin{array}{l}\text { Upper mountain forests, } \\
\text { tall kau, mamane }\end{array}$ & $\begin{array}{l}\text { Upper forests of Mauna Kea and } \\
\text { Mauna Loa }\end{array}$ \\
\hline $\begin{array}{l}\text { Hawail akepa (akepa) } \\
\text { (Loxops coccinea coccinea) }\end{array}$ & Native forests & $\begin{array}{l}\text { Widely scattered on Mauna Kea, } \\
\text { Mauna Loa, and Hualalai }\end{array}$ \\
\hline Ou (Psittirostra psittacea) & $\begin{array}{l}\text { Dense mountain rain forest } \\
\text { with fern understory }\end{array}$ & \\
\hline Palila (Psittirostra bailleui) & $\begin{array}{l}\text { Mamane-naio forests, } \\
7000-9000 \mathrm{ft}\end{array}$ & Mauna Kea \\
\hline $\begin{array}{l}\text { Hawaiian hoary bat } \\
\text { (Lasiunus cinereus semotus) }\end{array}$ & $\begin{array}{l}\text { Mature ohia-lehua and koa } \\
\text { forests }\end{array}$ & \\
\hline
\end{tabular}


Table 2.12. Summary of employment statistics for major agricultural activities in Puna

\begin{tabular}{lcc}
\hline & \multicolumn{2}{c}{ Employment } \\
\cline { 2 - 3 } & Full-time & $\begin{array}{c}\text { Seasonal or } \\
\text { part-time }\end{array}$ \\
\hline Sugar & 428 & \\
Papava & 265 & 227 \\
Macadamia & 81 & 205 \\
Anthurium & 95 & 235 \\
Other flowers & 116 (County) & 67 (County) \\
Truck farming & 30 & \\
\hline
\end{tabular}

Source: County of Hawaii Research and Development Department and State of Hawaii Department of Agriculture, unpublished data, 1976.

which can reclassify urban or conservation land (such as that around the governmental well site) for industrial or other urban-type uses. and (2) the urban land is under the zoning powers of the county. Environmental laws are administered at the state level, its agency being the Environmental Quality Comission. (An environmental impact statement would be examined by the Commission, for example.) Exploration for geothermal resources and drilling to exploit them is subject to regulation by the State Department of Land and Natural Resources. Energy policy, as well as economic policy for the state, generally is centered in Its Department of Planning and Economic Development. Research for new energy sources is centered in the University of Hawaii. 
1. University of Hawail, Atlas of Howaii, Department of Geography, University of Hawail Press, Honolulu, 1974.

2. The World AZmanac, Newspaper Enterprise Assoc., Inc., New York, 1976.

3. "National Registry of Natural Landmarks," Fed. Regist. 39(112): 20405-56 and $39(203)$ : 37225-26 (1974).

4. G. A. Macdonald and A. I. Abbott, Volcanoes in the Sea-The Geology of Howaii, University of Hawail Press, Honolulu, 1970.

5. H. T. Stearns, Geology of the State of Howaii, Pacific Books, Publishers, Palo Alto, Calif., 1966.

6. J. I. Coffman and C. A. von Hake, eds., Earthquake History of the United States, National Oceanic and Atmospheric Administration, U.S. Dept. of Commerce, U.S. Govt. Printing Office, Washington, D.C., 1973.

7. Untversity of Hawal1, The Howaii Geothemal Project. Initial Phase II Progress Report, Honolulu, February 1976. 
8. George Keller, "Research Drill Hole at the Sumit of Kilauea Volcano, Hawail," in The Utilization of Volcano Energy, ed. J. L. Colp and A. S. Furumoto, Sandia Laboratories, Albuquerque, N.M., 1974.

9. Peter Krooprick, "Memorandum to Robert Kamins - Results of Chemical Analysis of Water Samples," Department of Oceanography, Untversity of Hawait, Manoa, 1976.

10. D. Blumenstock and S. Price, "The Climate of Hawaii," Climates of the States, vol. 2, Water Information Center, Inc., Port Washington, N.Y., 1974.

11. E. Mayr, Populations, Species and Evolution, Belknap Press of Harvard University Press, Cambridge, 1970.

12. R. H. MacArthur and E. O. Wilson, The Theory of Is Zand Biogeogrophy, Princeton University Press, Princeton, 1967.

13. U.S. Dept. of the Interior, Threatened Wildlife of the United States, 1973 ed., Fish and Wildilfe Service, Bureau of Sport Fisheries and Wildilfe, 1973.

14. R. T. Peterson, A Field Guide to Western Birds, Houghton-Mifflin Co., Boston, 1941. 
15 A. J. Berger, Birds of the Geothermal Test Site, Puna, Howaii. HGA Preliminary Environmental Analysis, UnIversity of hawail, Honolulu, 1976. 
3. POTENTIAL ENVIRONMENTAL IMPACTS

\subsection{PHYSICAL ENVIRONMENT}

\subsubsection{Land use}

The project site presently occupies 1.6 ha ( 4 acres) and has disturbed an estimated 4 to 6 ha (10 to 15 acres) of the surrounding land. Agricultural, residential, recreational, and archaeological uses are present in the surrounding area but are located at some distance from the site. No industries are situated nearby. Because no future construction is planned during the well-testing phase of this project, additional conflicts in land use will not occur beyond those impacts which already exist. Noise, aesthetic, and visual effects from increases in activity and steam plumes will pose the greatest potential impact.

A potential land use conflict may also exist with the nearby Lava Tree State Park. Constituting a 6.9-ha (17-acre) parcel, this park is primarily of geologic interest and is located $0.8 \mathrm{~km}(0.5 \mathrm{mile})$ west and $1.8 \mathrm{~km}$ ( 1.1 miles) north of the well site. However, the well will not be visible from roads leading into the park, and general activities at the well will not be visible from within the park boundaries. In addition, a state forest reserve is located an estimated $11 \mathrm{~km}$ ( $7 \mathrm{miles}$ ) from the project site, and parts of the Hawail Volcanoes National Park are in the southwest portion of the Pune district. It is doubtful that the project's testing phase would create any visual or aesthetic impacts on these regions. 
Because the well is located on a recent (1955) K1lauea lava flow, encroachment upon agricultural or archaeological priorities are minimal. The nearest economic crops consist primarily of sugar cane, papaya, and orchids and are located several miles from the drill site. Archaeological material or workings are also located at substantial distances from the site. If any historical material had been present in the area, it has since been buried by the recent lava flows.

Only one occupied dwelling exists within 1 mile of the site. Noise, which is the only foreseeable potential impact on these residents, is expected to be below the "Discretionary - Normally Acceptable" level of $65 \mathrm{~dB}(\mathrm{~A}) .1$ Based on normal attenuation calculations, there would be a drop of $75 \mathrm{~dB} 1 \mathrm{mile}$ from the well without credit for screening or other noise reduction factors such as temperature, humidity, and terrain.

\subsubsection{Water use}

Water use and consumption during the testing phase will consist solely of personnel and maintenance use. The necessary water probably will be trucked or brought in thermos containers to the site. Because no add1tional drilling or cooling operations will be conducted, water use will be minimal and will not conflict with the freshwater requirements of the surrounding area.

The exact groundwater regime has not been determined. Although the well probably draws from a water system confined by nearly vertical rift-zone 
dikes, the degree of isolation within those dikes is not certain (Sect. 3.1.4). Water tables in the surrounding area are predominantly basal water and are significantly lower than water levels at the drill site. It is therefore unlikely that surrounding groundwater levels outside the diked area containing the drill site will be affected when geothermal fluids are pumped from the project site. More hydrological data will be necessary before any significant evaluations can be made. In addition, the short duration of the proposed flow test will result in insufficient fluid volume to affect the general groundwater regime.

\subsubsection{Air quality}

Gases associated with the geothermal fluids have proven to be near ambient conditions thus far. However, flashing of the well has only been accomplished intermittently for short periods of time. It is questionable whether or not the fluids at the base of the well have yet reached the wellhead. If gaseous concentrations during the testing phase continue at their present levels, the impact upon the surrounding area will be negligible. However, these concentrations may change considerably as monitoring continues at the wellhead and therefore may present potential environmental effects not presently anticipated. Alr quality may be further influenced by other factors, particularly the water vapor released during the flashing phases. Due to the moderate and often windy climate of the area, this Increase in moisture will generally have little effect on local conditions. Effects from fugltive dust or vehicle emissions will be negligible. 
Air quality samples were taken at the wellhead during flashing trial runs on May 1 and 2 and on June 24, 25, and 26 of this year. These readings were found to be less than the detection threshold for concentrations of hydrogen sulfide, sulfur dioxide, carbon monoxide, and nitrogen dioxide; carbon dioxide concentrations were also low. Table 3.1 compares the air quality during flashing with current levels for the Sulfur Banks and with past levels for the Sulfur Banks and Puna. Comparisons between the air quality at the wellhead and other locations on the Island of Hawaii are listed in Table 3.2 .

Table 3.1. Comparison of past and current fixed gas aerometric data at the Sulfur Banks and HGP drill site (Puna)

\begin{tabular}{|c|c|c|c|c|c|c|}
\hline \multirow{3}{*}{ Gas } & \multicolumn{6}{|c|}{ Concentration (ppm) } \\
\hline & \multicolumn{2}{|c|}{$1971-1975$} & \multicolumn{2}{|c|}{ Mav 1-2, 1976} & \multicolumn{2}{|c|}{ June 24-26, 1976} \\
\hline & Sulfur Banks & Puna & Sulfur Banks & Puna & Sulfur Banks & Puna \\
\hline $\mathrm{H}_{2} \mathrm{~S}$ & $\leqslant 5$ & $<0.5$ & $3-4$ & $<0.2$ & $6.4 \pm 0.8$ & $<0.2$ \\
\hline $\mathrm{SO}_{2}$ & $<25$ & $<0.5$ & $14-16$ & $<0.5$ & $18.0 \pm 2.2$ & $<0.5$ \\
\hline $\mathrm{CO}^{2}$ & $\leqslant 3$ & $<0.5$ & $1.3-2.0$ & $<0.5$ & $5.1 \pm 1.3$ & $<0.5$ \\
\hline $\mathrm{CO}_{2}$ & & & $>1000$ & 330 & $1750 \pm 650$ & 360 \\
\hline $\mathrm{NO}_{2}$ & $<0.2$ & & $<0.2$ & $<0.2$ & $<0.1$ & $<0.1$ \\
\hline
\end{tabular}

Source: University of Hawaii, Environmental Baseline Study for Geothermal Development in Puna, Hawaii, Hawaii Geothermal Project, Honolulu. September 1976.

Table 3.2. Aerometric data for June 24-26, 1976, 15 HGP.Puna and other sites, Island of Hawaii

\begin{tabular}{lccccc}
\hline & \multicolumn{5}{c}{ Concentration (ppm) } \\
\cline { 2 - 6 } Gas & \multicolumn{1}{c}{ Sulfur Banks } & Halemaumau & HGP.Puna & Kilauea caldera \\
\cline { 2 - 6 } & Solfotara & Steam vent & Kau & . & \\
\hline $\mathrm{H}_{2} \mathrm{~S}$ & $6.4 \pm 0.8$ & 1 & $<0.25$ & $<0.2$ & $<0.25$ \\
$\mathrm{SO}_{2}$ & $18.0 \pm 2.2$ & 4.5 & 7.2 & $<0.5$ & 0.5 \\
$\mathrm{CO}^{2}$ & $5.1 \pm 1.3$ & $\sim 2$ & $<0.5$ & $<0.5$ & $<0.5$ \\
$\mathrm{CO}_{2}$ & $1750 \pm 650$ & 440 & 400 & 360 & 385 \\
$\mathrm{NO}_{2}$ & $<0.1$ & $<0.1$ & $<0.1$ & $<0.1$ & $<0.1$ \\
\hline
\end{tabular}

Source: University of Hawaii, Environmental Baseline Study for Geothermal Development in Puna, Hawaii, Hawaii Geothermal Project, Honolulu, September 1976. 
Additional tests were conducted during the flashing to determine the possible presence of sulfur trioxide or sulfuric acid aerosols. Both the barium chloride and lead chloride tests yielded no sulfide precipitate, thus implying a negative finding. Tests for mercury were also conducted for the well site emissions. The results of the samples taken in May 1975, May 1976, and June 1976 do not exceed $1.2 \mu \mathrm{g} / \mathrm{m}^{3}$ of $\mathrm{drill}$ site air and are less than ambient conditions over other volcanic areas of the Island.

It is apparent that, at these present levels of possible contaminants, well tests will not provide hazardous or toxic 1mpacts on the local air quality. Monitoring will be performed, however, throughout the entire testing phase to determine and possibly regulate any variation from these values. All potentially harmful emissions will be controlled in compliance with the State of Hawail Department of Health, Public Health Regulations regarding Ambient Air Quality Standards (Chap. 42) and Air Pollution Controls (Chap. 43).

\subsubsection{Water quality}

The impact of a flow test on groundwater is difficult to determine. Too little is known at this time about the nature of groundwater in the region. A substantial part of the groundwater could be either basal water in a Ghyben-Herzberg lens or confined water wedged between dikes or fault barrfers. If salt water does underlie fresh water, however, extensive flow testing could eventually lead to saltwater encroachment. A general 
lowering of the water table and saltwater encroachment could take place if production water is not returned to the reservoir. An unlined 20-ftdeep sump located next to the well is to be used for returning spent water through the highly permeable substrate. This practice might not be entirely effective because evaporation losses could reduce the quantity of recharge. Also, if the salinity of production water begins to rise due to saltwater encroachment, injection through the unlined sump might contaminate a shallow aquifer.

It is not known precisely what will happen to the water after it enters the sump and filtrates into the substrate. A complex system of dikes could trap it at shallow depth. If a large quantity of fluid passes through the sump, it could spread out laterally, parallel to the strike of the dikes (along the rift zone), or overspill beyond the dike system. Another possibility is that silica dissolved in the hot water will precipitate as it cools. Precipltation of silica might clog the pore spaces in lava underlying the sump, but it is not expected to occur during the short duration of the flow tests.

Although saltwater contamination of a shallow aquifer is conceivable, the nearest operating water well is over 3 miles from the test well. At least two wells have been drilled for agricultural use within about 1 mile of the site. One of these wells was orilled for the Hawail Agricultural Experiment Station. The water in the wells was basal rather than being associated with dikes and it was too saline to be used even for irrigation. 
Several shallow observation wells and flow tests over an extended period of time will provide the necessary data for determining whether drawdown and saltwater encroachment are significant.

Groundwater quality may be affected by contamination with injected fluids. At the present wellhead pressure of 67 psi, flow tests will be conducted at rates of 10 to $20 \mathrm{bbl} / \mathrm{min}$. High-temperature fluids will be withdrawn. The volume of water to be injected will be slightly less than that of withdrawal due to evaporation. ${ }^{2}$ During a 6-hr trial flow test taken on June 24 , 1976, the following concentrations were found in the geothermal fluid:

\begin{tabular}{lc}
\hline Component & Concentration (ppm) \\
\hline $\mathrm{Na}^{+}$ & 400 \\
$\mathrm{~K}^{+}$ & 50 \\
$\mathrm{Ca}^{2+}$ & 5 \\
$\mathrm{Mg}^{2+}$ & 1 \\
$\mathrm{Cl}^{-}$ & 600 \\
$\mathrm{SO}_{2}{ }^{-2}$ & 160 \\
$\mathrm{SLO}_{2}$ & 151 \\
$\mathrm{TDS}$ & 2322 \\
\hline
\end{tabular}

These values imply only slightly saline water having a total dissolved solids concentration lower than that found in wany of the surrounding basal water wells. However, due to the uncertain nature of the actual source of this geothermal water sample, these concentrations may change as flow tests continue during more intensive studies. 
Accidental spills may also occur at the surface of the project site. High silica concentrations within the heated fluids may begin to precipitate during injection, and the sump could develop a somewhat impermeable seal. Water may be unable to percolate through the basalts at a sufficient rate and therefore may overflow onto the surface. Surface contamination may occur, and groundwater quallty may subsequently decrease. However, surface streams are only intermittent, thereby limiting their potential chemical or thermal contamination. Blowouts may also pose potential impacts to water quality, although they are more likely to occur during the drilling phase of the well. Because the Hawail Geothermal Project well is already established and maintains a relatively low wellhead pressure, a blowout is unlikely. A potential for cracking of the wellhead could result from rapid increase in temperature during startup. Steps are being taken to prevent this (Sect. 1.2).

\subsection{IMPACTS ON THE BIOLOGICAL ENVIRONMENT}

Potential impacts on biota resulting from the proposed well test include destruction of habitat due to increased activity, displacement of animals due to human activity and noise, and effects of effluents (principally hydrogen sulfide and mercury) on plants.

\subsubsection{Impacts due to destruction of habitat}

The early successional habitat surrounding the site is not suitable for endemic wildilfe (Sect. 2.9.2). The amount of vegetation that potentially will be destroyed, if any, is 11ttle over the existing cleared area. 


\subsubsection{Impacts due to noise}

An unmuffled venting geothermal well may cause noise levels of $120 \mathrm{~dB}(\mathrm{~A})$ $100 \mathrm{ft}$ away. A silencer of the type to be used at HGP-A is expected to reduce noise levels to $100 \mathrm{~dB}(\mathrm{~A})$ or less $100 \mathrm{ft}$ from the well. Attenuation of noise level with distance will result in a reduction of $75 \mathrm{~dB}(\mathrm{~A})$ within 1 mile of the well.

Noise impacts on humans depend to a high degree on Individual variation in acuity and personal experience as well as on intensity and frequency of the noise. Wildlife also differ greatly in their sensitivity to various frequencies and intensity. Noise is any undesirable sound, and for analytical purposes, it is assumed to decrease in desirability as loudness increases. Loudness (intensity) of sound is measured in decibels using a logarithmic scale of comparative intensity with respect to the threshold of human hearing. Using this scale, an increment of $1 \mathrm{~dB}$ corresponds to an increase of $26 \%$ in intensity. Table 3.3 gives some comon sound levels. The human ear perceives sounds of higher frequency at lower intensity than those of Intermediate frequency; therefore, noise measurements are usually weighted to account for this by using the " $A$ " [dB (A)] scale.

The expected noise levels may cause some wildlife in surrounding habitats, such as the introduced birds (Japanese white-eye, cardinal, etc.) (Sect. 2.9.2) and the introduced mongoose, to be displaced. Individuals are not Ifkely to find suitable habitat elsewhere due to intraspecific 
Table 3.3. Common sound levels

\begin{tabular}{lcc}
\hline & $\begin{array}{c}\text { Intensity } \\
\left(\mu \mathrm{W} / \mathrm{m}^{2}\right)\end{array}$ & $\begin{array}{c}\text { Sound level } \\
{[\mathrm{dB}(\mathrm{A})]}\end{array}$ \\
\hline Threshold of hearing & $10^{-6}$ & 0 \\
Rustling leaves & $10^{-4}$ & 20 \\
Talking (at $3 \mathrm{ft})$ & $10^{-2}$ & 40 \\
Singing crickets & $10^{-1}$ & 50 \\
Noisy office & 1 & 60 \\
Subway & $10^{4}$ & 100 \\
Threshold of pain & $10^{6}$ & 120 \\
& & \\
\hline
\end{tabular}

competition; therefore, they may be assumed lost. The total number displaced will be very small in relation to the populations present in the area, and since these animals are introduced, a reduction in their populations would, in most cases, be considered beneficial.

Noise may cause the native Hawailan hawk to avoid the area. However, since this region is not good habitat for the hawk and is small in relation to its hunting territory, no effect is anticipated. The area is removed from the likely roosting area of the Hawalian hoary bat, but Individuals may fly through the area in their crepuscular hunting forays. Reduction of roosting habitat rather than reduction of hunting is the more likely contributor to the decline of this species. Because it is unlikely that noise will penetrate to potential roosting areas in the mature forests several miles away, the effect of the well test should be minimal. It should be pointed out that, if the well testing phase is successful and further development is anticipated, potential habitat destruction of the bat and, less likely, the hawk may result. 


\subsubsection{Impacts due to gaseous effluents}

Potential effluents that may be evolved from the well during the well testing program are largely unknown. Hydrogen sulfide, it is known, will develop; however, the concentration of hydrogen sulfide in the fluid and the rate at which it will develop cannot be ascertained without further testing. This is one of the goals of the program. Hydrogen sulfide is a normal constituent of volcanic releases and therefore is not uncommon to the area. Results of ongoing research indicate that hydrogen sulfide is toxic to a variety of crops and temperate forest trees at concentrations of $300 \mathrm{ppb}^{3}$ It is noticeable to humans at very low concentrations - far below the levels toxic to plants. No effect on local habitats is expected during the well test because of the expected low concentration of less than $200 \mathrm{ppb}$ before atmospheric dilution.

Heavy metals, notably mercury, are also evolved in an aerosol state from geothermal fluids. Sampling by the staff of the Hawaii Geothermal Project has given high priority to geotoxicology of mercury. Representative plant species in the area of the well yielded mercury levels that were relatively uniform in the various species and individuals. The mean levels at the site were somewhat lower than concentrations found at Volcano House and Sulfur Banks. Mercury tends to accumulate over long periods of time in plants and can be concentrated in higher levels of the food chain. Nevertheless, no significant accumulation is expected during the six-month well test because the duration of the test will not allow enough time for accumulation to any significant degree. 
The flow test will be monitored for other potentially toxic substances (e.8., arsenic, lead, and selenium). Further geochemical, geotoxicological, and ecophysiological studies will be undertaken during the well test.

\subsubsection{Impacts due to liquid effluents}

Ecological impacts due to the liquid effluents envisioned would be a result of unexpected or accidental surface spillage of geothermal fluids. Impacts on groundwater are discussed in Sects. 3.1 .2 and 3.1.4. Surface spillage would likely affect only a very small area in the vicinity of the site (Sect. 3.5) because effluents will drain through the porous substrate and not affect the surface-rooted plants or aquatic environments.

\subsection{SOCIOECONOMIC EFFECTS}

The six-month well test should have negligible negative effects on local social economics. No new personnel will be required to take up residence at the site, and no effects on employment or trade are expected. Traffic and increased activity should have minor effects. Some obstruction of traffic on Pahoa-Pohoiki Road can be expected due to construction traffic at the well site, but this should be temporary and should not take place during peak hours. The Project may attract some sightseers; again, this should be temporary. Potential effects on groundwater and local agriculture are not expected to materialize. Noise should not be noticeable to local residents. Noticeable levels of hydrogen sulfide are expected. 
This should concern only workers at the site, onlookers, and a few passersby. Naturally released hydrogen sulfide is noticeable at other tourist spots in the area.

Native Hawailan religion embraces concepts that elevate volcanoes and volcanism to an extremely important position in their beliefs. The project may attract controversy by seemingly disturbing this focus of indigenous religion. Steps have already been taken to inform religious leaders about the project, and on occasion, representatives have been invited to view and bless the project.

\subsection{IMPACT CONTROL PROGRAMS}

A silencer (Sect. 1.2) will be installed prior to startup of the well test program. This piece of equipment should decrease noise levels to less than $100 \mathrm{~dB}(\mathrm{~A}) 100 \mathrm{ft}$ from the well. Noise will be monitored periodically during the well test. If levels reached are in excess of levels shown in Table 3.4, steps will be taken to protect workers from effects of noise. Mercury and hydrogen sulfide will be monitored during the course of the well test. If mercury levels approach the toxic threshold of $0.1 \mathrm{mg} / \mathrm{m}^{3}$ in air in the vicinity of the site, ${ }^{4}$ steps will be taken to control this emission up to and including shutdown. The onsite concentration of hydrogen sulfide is not expected to exceed $200 \mathrm{ppb}$. The occupational exposure limit is $2000 \mathrm{ppb} .^{4}$ Monitoring of hydrogen sulfide will permit adequate precaution to be taken for personnel safety should higher concentrations be encountered. 
Table 3.4. Permissible noise exposures

\begin{tabular}{cc}
\hline Duration per day (hr) & $\begin{array}{c}\text { Sound level [dB(A)], } \\
\text { slow response }\end{array}$ \\
\hline 8 & 90 \\
6 & 92 \\
4 & 95 \\
3 & 97 \\
2 & 100 \\
1.5 & 102 \\
1 & 105 \\
0.5 & 110 \\
0.25 & 115 \\
\hline
\end{tabular}

Source: U.S. Dept. of the Interior, Final Environmental Statement for the Geothermal Leasing Program, vol. I. 1973.

Because soils in the drill site area are not prone to erosion, erosion controls are not necessary.

\subsection{POTENTIAL ACCIDENTS}

During the course of the well test program, the only potential accidents considered are (1) rupture of the casing due to thermal expansion or earthquake and (2) spillage from injection sump or from destruction of the well due to lava flow.

Rupture of the well casing or wellhead may cause an expected release of steam and fluids to the local environs. Effects would be expected to cover a small area immediately adjoining the site. Only temporary damage to local habitats would be expected. Spillage due to overflow from the sump would likely percolate through the lava substrate after a short distance. Again, no permanent damage would be expected. If Kilauea 
erupted and lava Inundated the site, the effects of the lava flow would be far more damaging than effects from the well. The major effect of such inundation would be the necessity of repairing the wellhead.

\subsection{POTENTIAL LONG-TERM ENVIRONMENTAL EFFECTS}

No long-term effects are expected due to the well test program. However, long-term effects could result if the site were developed for full-scale production. A reevaluation of environmental effects will have to be undertaken prior to such development and after completion of environmental studies conducted during and after the well test. 
REFERENCES FOR SECTION 3

1. U.S. Dept. of Housing and Urban Development, Noise Abatement and Control: Department Policy, Implementation Responsibilities, and Standards, Circ. 1390.2, August 1972.

2. University of Hawail, Environmental Baseline Study for Geothermal Development in Puna, Howaii, Hawail Geothermal Project, Honolulu, September 1976.

3. C. R. Thompson, Behavior of $\mathrm{H}_{2} \mathrm{~S}$ in the Atmosphere and Its Effects on Vegetation. Quarterly Report, May 1, 1976 - July 31, 1976, Statewide Alr Pollution Research Center, University of California, Riverside, 1976.

4. Occupational Safety and Health Administration, Fed. Regist. 105: 10465-714 (1971). 
4. CONFLICTS WITH FEDERAL, STATE, AND REGIONAL OR LOCAL PLANS

Because of Federal, state, and local involvement in planning and funding of the Hawaii Geothermal Project, no conflicts appear to exist. 